Article

\title{
Exogenous Application of Zinc to Mitigate the Salt Stress in Vigna radiata (L.) Wilczek-Evaluation of Physiological and Biochemical Processes
}

\author{
Hassan S. Al-Zahrani ${ }^{1}$, Hesham F. Alharby ${ }^{1}$, Khalid Rehman Hakeem ${ }^{1, *}$ (D) and Reiaz Ul Rehman ${ }^{2}$ \\ 1 Department of Biological Sciences, Faculty of Science, King Abdulaziz University, Jeddah 21589, Saudi Arabia; \\ hsalzahrani@kau.edu.sa (H.S.A.-Z.); halharby@kau.edu.sa (H.F.A.) \\ 2 Department of Bioresources, University of Kashmir, Hazratbal, Srinagar 190006, India; \\ rreiazbiores@gmail.com \\ * Correspondence: khakim@kau.edu.sa or kur.hakeem@gmail.com
}

Citation: Al-Zahrani, H.S.; Alharby, H.F.; Hakeem, K.R.; Rehman, R.U Exogenous Application of Zinc to Mitigate the Salt Stress in Vigna radiata (L.) Wilczek-Evaluation of Physiological and Biochemical Processes. Plants 2021, 10, 1005 https://doi.org/10.3390/ plants10051005

Academic Editors: Hazem M. Kalaji, Francisco J. Corpas, Manzer Hussain Siddiqui and M. Nasir Khan

Received: 12 April 2021

Accepted: 14 May 2021

Published: 18 May 2021

Publisher's Note: MDPI stays neutral with regard to jurisdictional claims in published maps and institutional affiliations.

Copyright: (c) 2021 by the authors. Licensee MDPI, Basel, Switzerland. This article is an open access article distributed under the terms and conditions of the Creative Commons Attribution (CC BY) license (https:// creativecommons.org/licenses/by/ $4.0 /)$.

\begin{abstract}
Salt stress adversely affects the growth and productivity of crops. However, reports suggest that the application of various micronutrients could help the plant to cope with this stress. Hence, the objective of the study was to examine the effect of exogenous application of $\mathrm{Zinc}(\mathrm{Zn})$ on salt tolerance in Vigna radiata (L.) Wilczek (mungbean). Mungbean is considered to be an economically important crop and possess a strategic position in Southeast Asian countries for sustainable crop production. It is rich in quality proteins, minerals and vitamins. Three weeks old grown seedlings were subjected to $\mathrm{NaCl}(150 \mathrm{mM}$ and $200 \mathrm{mM})$ alone or with $\mathrm{Zn}(250 \mu \mathrm{M})$. After 21 days of treatment, plants were harvested for investigating morphological, physiological and biochemical changes. We found that the $\mathrm{Zn}$ application mitigates the negative effect upon plant growth to a variable extent. This may be attributed to the increased shoot and root length, improved chlorophyll and carotenoid contents, enhanced total soluble sugar (TSS), total soluble protein (TSP) and proline accumulation, decreased $\mathrm{H}_{2} \mathrm{O}_{2}$ content and increased enzymatic antioxidant activities. $\mathrm{Zn}$ 's application improved the performance of the enzymes such as phenylalanine ammonia-lyase (PAL) and tyrosine ammonialyase (TAL) of the secondary metabolism, which resulted in the improvement of total phenol and flavonoids. The antioxidant activities such as 1,1diphenyl 2-picryl hydrazine (DPPH) and ferrous reducing antioxidant power assay (FRAP) of the plants also showed improved results in their salt only treatments. Furthermore, hydrogen peroxide $\left(\mathrm{H}_{2} \mathrm{O}_{2}\right)$ and superoxide radical (SOD) scavenging activity were also improved upon the application of $250 \mu \mathrm{M}$ zinc. Thus, $\mathrm{Zn}$ application in low doses offers promising potential for recovering plants suffering from salinity stress. In conclusion, we assume that zinc application improved salt tolerance in mungbean through the improvement of various physiological and photochemical processes which could prove to be useful in nutrient mediated management for crop improvement.
\end{abstract}

Keywords: antioxidants; phenylalanine ammonia-lyase; reactive oxygen species; salinity; tyrosine ammonia-lyase; zinc

\section{Introduction}

Amongst abiotic stresses salt is one of the main cause for restraining the growth in crops [1]. The salinization of soil represents a major hurdle in agricultural expansion to increase crop production [2]. Increasing distribution of soil salinity causes great economic loss by a detrimental reduction in yield, thus posing a challenge for future food production. Nearly $71 \%$ of the earth's area is salinized, $80 \%$ of which is due to natural processes and $20 \%$ is the result of anthropogenic activities [3]. The regions where soils are mainly affected by salt belong to arid and semi-arid, however, it is not restricted to these regions only as it has been recorded in a wide range of altitudes with different climatic conditions. The most prevalent soluble salt is $\mathrm{NaCl}$ followed by $\mathrm{Na}_{2} \mathrm{SO}_{4}, \mathrm{CaSO}_{4}$ and $\mathrm{KCl}$ [4]. 
Plants grown in the salt-affected soil undergo alterations in their physiology and metabolism at a cellular as well as whole-plant level. Based on their salt tolerance, plants are categorized into salt-tolerant, salt-sensitive and intermediately tolerant [5]. Salinity is deleterious to plant growth from the germination stage to the flowering and fruiting stage, resulting in decreased yield [6]. It causes osmotic and ionic stress by affecting its water relations [7]. Salinity stress causes the excessive generation of reactive oxygen species (ROS) and the balance between their generation and neutralization determines the plants survival [8]. This imbalance in ROS initiates the cell damage rapidly by acting as a trigger to a chain of reactions making the plant susceptible to the oxidative process leading to significant disruption and damage to cellular structures $[9,10]$.

For protecting themselves plants counter these effects by their innate antioxidative defense machinery comprised mainly of enzymatic and non-enzymatic elements [11,12]. At times, plants' self-defense is insufficient to combat the negatives of salt stress. To overcome these effects, some substances are exogenously applied to plants which include macronutrients, micronutrients and osmolytes [13,14]. Among the essential micronutrients, zinc $(\mathrm{Zn})$ is reported to have a significant potential to alleviate plant abiotic stress [15]. Under unfavorable conditions, foliar application of $\mathrm{Zn}$ enhances plant growth and development [16], including mitigation of salt stress [17], accompanied by improvements in plant growth by boosting chlorophylls and consequently photosynthesis [18]. Zn protects the membranes against oxidative as well as peroxidative damages by stabilizing membrane integrity and permeability [19]. Zn acts as a vital component of various important enzymes, stabilizer of proteins including the DNA-binding proteins (Zn-fingers) [20,21]. It is vital to superoxide dismutase (SOD) as its $\mathrm{Cu} / \mathrm{Zn}$ isoforms are most copious in plants which are considered the first line of defense amongst the antioxidative enzymes. The application of $\mathrm{Zn}$ decreases the activity of membrane-bound NADPH oxidase, reduces photo-oxidation, increases activities of superoxide dismutase, catalase and peroxidase [22,23]. Zn has a pivotal role in DNA replication and thus alters the expression of several genes [24].

Amongst the micronutrients the $\mathrm{Zn}$ deficiency is dire amongst the plants cultivated on saline soils and around the globe, more than $50 \%$ of soil used for agriculture has low levels of available zinc for plants [25]. Taking into account, the increasing population, decreasing agricultural land, food security and balanced diet, we chose to work with legume namely mungbean (Vigna radiata L.) which is significantly affected by salinity. Legumes are the second important human food crop after cereals and among legumes mungbean is an important ancient food crop in Asia, said to be domesticated particularly in India which is the largest producer of mungbean followed by Pakistan. Mungbean is short duration legume and farmers grow it in-between the main successive crops as it fixes the atmospheric nitrogen by forming symbiotic association with Rhizobium bacteria which is also beneficial for the succeeding crop. It also has efficient tolerance towards adverse climatic conditions but drought and salt stress reduces its productivity [26].

The present study focused on understanding plant behavior including morphological and physiological modulations in response to salinity and exogenously applied $\mathrm{Zn}$. We aimed to assess the role of $\mathrm{Zn}$ in ameliorating the $\mathrm{NaCl}$ salt stress by improving various morphological and biochemical parameters in mungbean genotype-NCM-1 (NARCIslamabad) classified as belonging to an arid region. The role of zinc in alleviating salt stress has been evaluated by measuring its effect on electrolyte leakage, lipid peroxidation and $\mathrm{H}_{2} \mathrm{O}_{2}$ content under $\mathrm{NaCl}$ stress. Effect of $\mathrm{Zn}$ on osmolytes and major antioxidant enzymes have been assessed in salt-stressed seedlings. The outcome of this study will help us in understanding the salt stress alleviation by $\mathrm{Zn}$ supplementation and its role in plant growth, development and protection across the world, especially in arid and semiarid regions. 


\section{Results}

2.1. Effect of Salinity on Growth, Photosynthetic Pigments and Their Recovery by Exogenous Application of $\mathrm{Zn}$

$\mathrm{NaCl}, 250 \mu \mathrm{M} \mathrm{Zn}$ and cumulative application of $\mathrm{NaCl}+\mathrm{Zn}$ significantly affected the FW, DW, RWC, shoot and root length of seedlings (Figure 1). The fresh weight was decreased by $39.16 \%$ and $57.21 \%$ at $150 \mathrm{mM}$ and $200 \mathrm{mM} \mathrm{NaCl}$ treatment, respectively, for salt-only trials. Addition of Zn exhibited an increase in fresh weight by $30.89 \%$ and $43.25 \%$ at $150 \mathrm{mM}$ and $200 \mathrm{mM} \mathrm{NaCl}$ treatment, respectively. The dry weight was decreased by $32.98 \%$ and $44.50 \%$ at $150 \mathrm{mM}$ and $200 \mathrm{mM} \mathrm{NaCl}$ treatment, respectively, for salt-only trials. Addition of $\mathrm{Zn}$ exhibited an increase in dry weight by $12.36 \%$ and $27.10 \%$ at $150 \mathrm{mM}$ and $200 \mathrm{mM} \mathrm{NaCl}$ treatment, respectively. The relative water content (RWC) was reduced by $5.7 \%$ and $20.35 \%$ at $150 \mathrm{mM}$ and $200 \mathrm{mM} \mathrm{NaCl}$, respectively, for salt-only trials. Addition of $\mathrm{Zn}$ exhibited an increase in RWC by $14.30 \%$ and $13.78 \%$ at $150 \mathrm{mM}$ and $200 \mathrm{mM} \mathrm{NaCl}$ treatment, respectively. The root length was reduced by $25.26 \%$ and $46.84 \%$ at $150 \mathrm{mM}$ and $200 \mathrm{mM} \mathrm{NaCl}$, respectively, for salt-only trials. Addition of $\mathrm{Zn}$ exhibited an increase in root length by $74.64 \%$ and $77.22 \%$ at $150 \mathrm{mM}$ and $200 \mathrm{mM} \mathrm{NaCl}$ treatment, respectively. The shoot length was reduced by $21.56 \%$ and $31.71 \%$ at $150 \mathrm{mM}$ and $200 \mathrm{mM} \mathrm{NaCl}$, respectively, for salt-only trials. Addition of $\mathrm{Zn}$ exhibited an increase in shoot length by $16.52 \%$ and $10.90 \%$ at $150 \mathrm{mM}$ and $200 \mathrm{mM} \mathrm{NaCl}$ treatment, respectively.

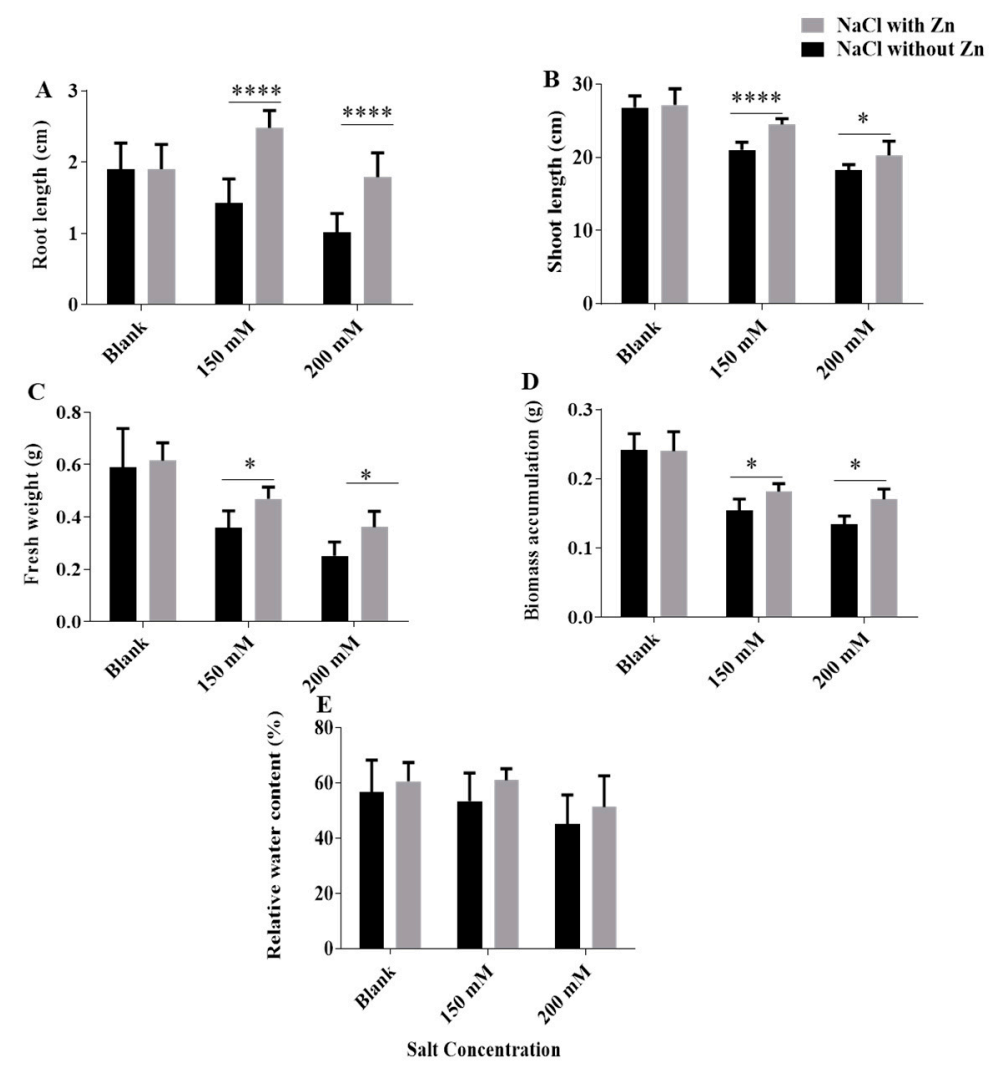

Figure 1. Effects of $\mathrm{NaCl}$ and Interactive effect of $\mathrm{NaCl}$ and $\mathrm{Zn}$ on (A) root length, (B) shoot length, (C) fresh weight, (D) biomass accumulation and (E) RWC of mungbean. The mean values with different letters across treatments are significantly different at $p<0.05 . *, * * * *$ represent the significant difference between the two columns under the bar.

The chl $a$ (chlorophyll-a), chl $b$ (chlorophyll-b) and carotenoid content of seedlings was reduced with salt treatments and an increase was observed by $\mathrm{Zn}$ supplementation (Figure 2). The total chlorophyll content was reduced by $40.33 \%$ and $41.65 \%$ at $150 \mathrm{mM}$ and $200 \mathrm{mM} \mathrm{NaCl}$, respectively, for salt-only trials. Addition of $\mathrm{Zn}$ exhibited an increase in total chlorophyll content by $8.40 \%$ and $15.68 \%$ at $150 \mathrm{mM}$ and $200 \mathrm{mM} \mathrm{NaCl}$ treatment, respec- 
tively. The carotenoid content was reduced by $23.58 \%$ and $30.54 \%$ at $150 \mathrm{mM}$ and $200 \mathrm{mM}$ $\mathrm{NaCl}$, respectively, for salt-only trials. Addition of $\mathrm{Zn}$ exhibited an increase in Carotenoid content by $14.99 \%$ and $12.96 \%$ at $150 \mathrm{mM}$ and $200 \mathrm{mM} \mathrm{NaCl}$ treatment, respectively.
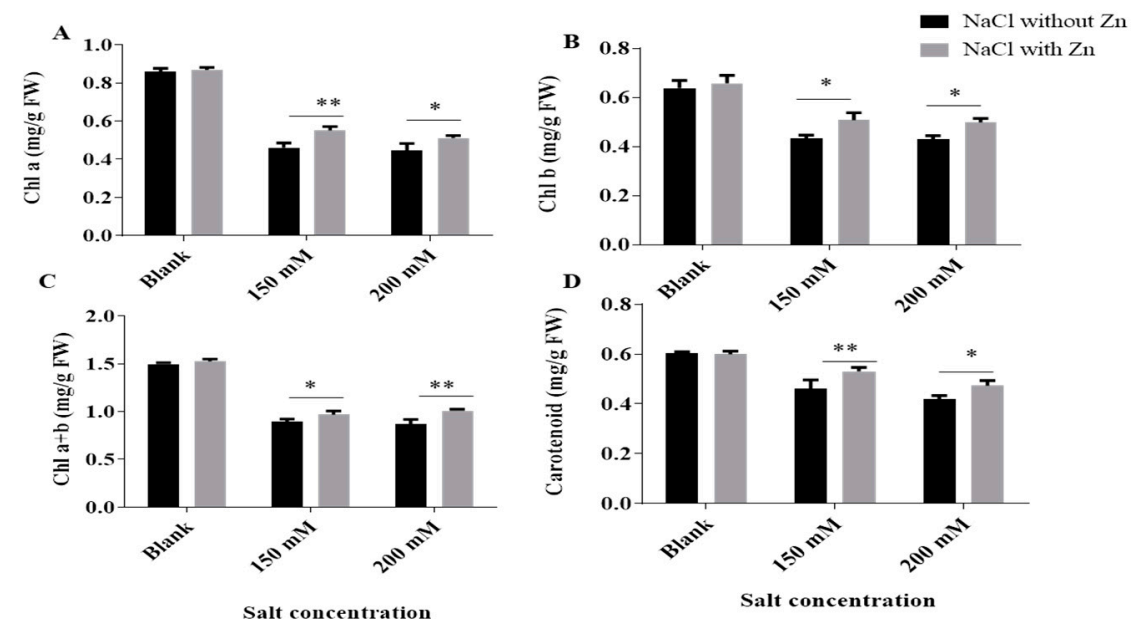

Figure 2. Effects of $\mathrm{NaCl}$ and interactive effect of $\mathrm{NaCl}$ and $\mathrm{Zn}$ on (A) chl a, (B) chl b, (C) chl a \pm b and (D) carotenoids of mungbean. The mean values with different letters across treatments are significantly different at $p<005$. ${ }^{*}{ }^{* *}$ represent the significant difference between the two columns under the bar.

2.2. Effect of Salt Stress on Membrane Stability Index (MSI), Thiobarbituric Acid Reactive Species (TBARS) Content and Hydrogen Peroxide $\left(\mathrm{H}_{2} \mathrm{O}_{2}\right)$ Content and Its Mitigation by $\mathrm{Zn}$

Membrane stability index (MSI), thiobarbituric acid reactive species (TBARS) content and hydrogen peroxide $\left(\mathrm{H}_{2} \mathrm{O}_{2}\right)$ content were significantly affected by $\mathrm{NaCl}, 250 \mu \mathrm{M}$ $\mathrm{Zn}$ and cumulative application of $\mathrm{NaCl}$ and $\mathrm{Zn}$ (Figure 3). Membrane stability index (MSI)/electrolyte leakage was elevated with increasing salinity by $31.39 \%$ and $34.93 \%$ at $150 \mathrm{mM}$ and $200 \mathrm{mM} \mathrm{NaCl}$, respectively, for salt-only trials. The addition of $\mathrm{Zn}$ reduced electrolyte leakage by $20.89 \%$ and $18.15 \%$ at $150 \mathrm{mM}$ and $200 \mathrm{mM} \mathrm{NaCl}$ treatment, respectively.
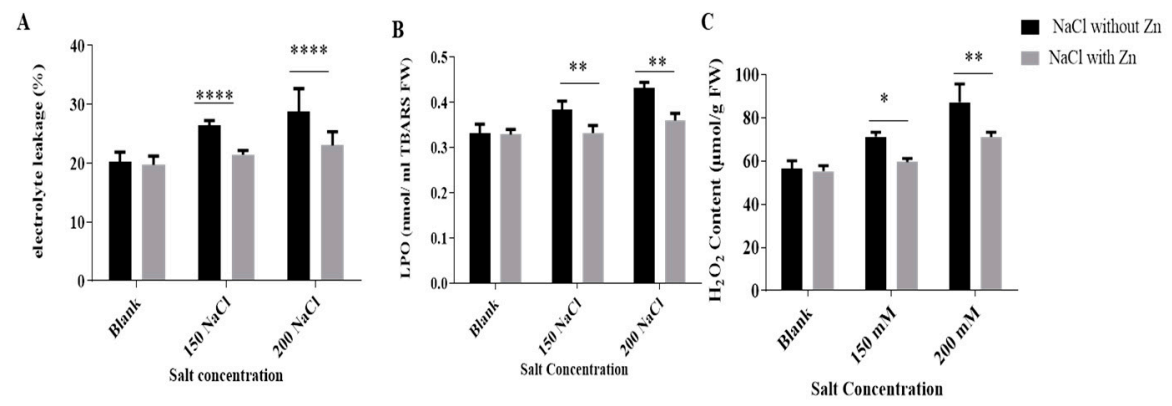

Figure 3. Effects of $\mathrm{NaCl}$ and interactive effect of $\mathrm{NaCl}$ and $\mathrm{Zn}$ on (A) MSI, (B) LPO and (C) $\mathrm{H}_{2} \mathrm{O}_{2}$ content of mungbean. The mean values with different letters across treatments are significantly

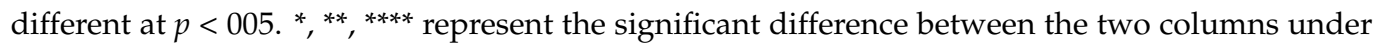
the bar.

The salt stress results in lipid peroxidation (LPO) as reflected by the increased TBARS content. LPO increased salinity by $16.86 \%$ and $29.84 \%$ at $150 \mathrm{mM}$ and $200 \mathrm{mM} \mathrm{NaCl}$, respectively for salt-only trials. The addition of $\mathrm{Zn}$ reduced electrolyte leakage by $13.47 \%$ and $16.56 \%$ at $150 \mathrm{mM}$ and $200 \mathrm{mM} \mathrm{NaCl}$ treatment, respectively. $\mathrm{H}_{2} \mathrm{O}_{2}$ content was increased salinity by $28.62 \%$ and $46.41 \%$ at $150 \mathrm{mM}$ and $200 \mathrm{mM} \mathrm{NaCl}$, respectively, for salt-only trials. The addition of $\mathrm{Zn}$ reduced $\mathrm{H}_{2} \mathrm{O}_{2}$ content by $16.45 \%$ and $18.28 \%$ at $150 \mathrm{mM}$ and $200 \mathrm{mM} \mathrm{NaCl}$ treatment, respectively. 


\subsection{Effect of Salinity and Exogenously Applied Zn on Osmolytes (Proline, TSS and TSP)}

$\mathrm{NaCl}, 250 \mu \mathrm{MZn}$ and combined $\mathrm{NaCl}$ with Zn significantly affected the osmolytes content of mungbean seedlings (Figure 4). The proline content increased salinity by $23.56 \%$ and $40.85 \%$ at $150 \mathrm{mM}$ and $200 \mathrm{mM} \mathrm{NaCl}$, respectively, for salt-only trials. The addition of $\mathrm{Zn}$ increased the proline content by $9.05 \%$ and $23.03 \%$ at $150 \mathrm{mM}$ and $200 \mathrm{mM} \mathrm{NaCl}$ treatment, respectively. The TSS content increased salinity by $11.48 \%$ and $42.26 \%$ at $150 \mathrm{mM}$ and $200 \mathrm{mM} \mathrm{NaCl}$, respectively, for salt-only trials. The addition of $\mathrm{Zn}$ increased the TSS content by $34.84 \%$ and $23.03 \%$ at $150 \mathrm{mM}$ and $200 \mathrm{mM} \mathrm{NaCl}$ treatment, respectively. The TSP content increased salinity by $36 \%$ and $65.38 \%$ at $150 \mathrm{mM}$ and $200 \mathrm{mM} \mathrm{NaCl}$, respectively, for salt-only trials. The addition of Zn increased the TSS content by 27.56 and $26.04 \%$ at $150 \mathrm{mM}$ and $200 \mathrm{mM} \mathrm{NaCl}$ treatment, respectively.

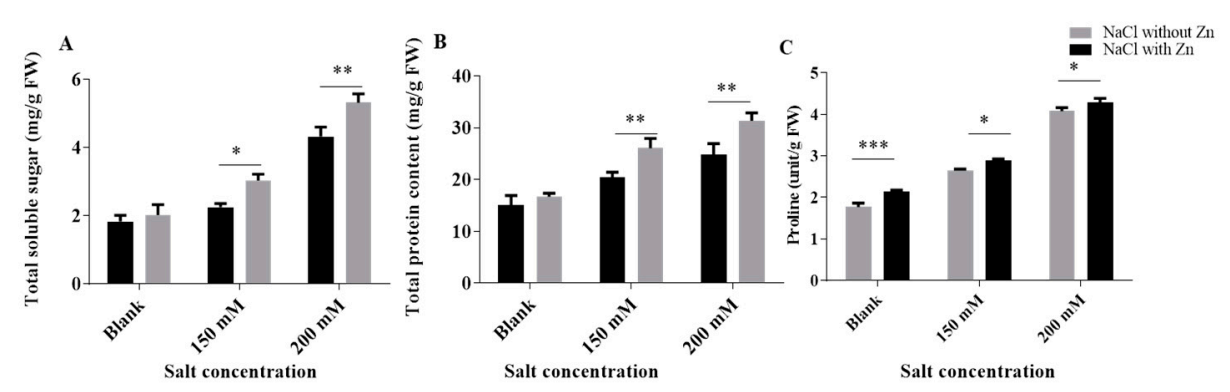

Figure 4. Effects of $\mathrm{NaCl}$ and interactive effect of $\mathrm{NaCl}$ and $\mathrm{Zn}$ on (A) TSS, (B) TPC and (C) proline content of mungbean. The mean values with different letters across treatments are significantly different at $p<0.05 .{ }^{*},{ }^{* *},{ }^{* *}$ represent the significant difference between the two columns under the bar.

\subsection{Effect of Salinity Stress and Zn on the Activity of Antioxidant Enzymes}

$\mathrm{NaCl}, 250 \mu \mathrm{M} Z \mathrm{Zn}$ and combined $\mathrm{NaCl}$ with $\mathrm{Zn}$ significantly affected the antioxidant enzymatic activity of mungbean seedlings (Figure 5). Superoxide dismutase (SOD) activity increased salinity by $18.77 \%$ and $43.24 \%$ at $150 \mathrm{mM}$ and $200 \mathrm{mM} \mathrm{NaCl}$, respectively, for salt-only trials. Addition of $\mathrm{Zn}$ increased the SOD activity by $15.45 \%$ and $8.52 \%$ at $150 \mathrm{mM}$ and $200 \mathrm{mM} \mathrm{NaCl}$ treatment, respectively. Catalase (CAT) activity increased salinity by $28.83 \%$ and $85.39 \%$ at $150 \mathrm{mM}$ and $200 \mathrm{mM} \mathrm{NaCl}$, respectively, for salt-only trials. Addition of $\mathrm{Zn}$ increased the CAT activity by $42.08 \%$ and $29.84 \%$ at $150 \mathrm{mM}$ and $200 \mathrm{mM} \mathrm{NaCl}$ treatment, respectively. Ascorbate peroxide (APX) activity increased salinity by $45.11 \%$ and $115.35 \%$ at $150 \mathrm{mM}$ and $200 \mathrm{mM} \mathrm{NaCl}$, respectively, for salt-only trials. Addition of $\mathrm{Zn}$ increased the APX activity by $40.79 \%$ and $11.57 \%$ at $150 \mathrm{mM}$ and $200 \mathrm{mM} \mathrm{NaCl}$ treatment, respectively. Guaiacol peroxide (GPOX/POD) activity increased salinity by $9.19 \%$ and $68.28 \%$ at $150 \mathrm{mM}$ and $200 \mathrm{mM} \mathrm{NaCl}$, respectively, for salt-only trials. Addition of $\mathrm{Zn}$ increased the POD activity by $16.84 \%$ and $11.93 \%$ at $150 \mathrm{mM}$ and $200 \mathrm{mM} \mathrm{NaCl}$ treatment, respectively. Glutathione-S-transferase (GST) activity increased salinity by $95 \%$ and $161 \%$ at $150 \mathrm{mM}$ and $200 \mathrm{mM} \mathrm{NaCl}$, respectively, for salt-only trials. Addition of $\mathrm{Zn}$ increased the GST activity by $62.82 \%$ and $28.16 \%$ at $150 \mathrm{mM}$ and $200 \mathrm{mM} \mathrm{NaCl}$ treatment, respectively. Glutathione reductase (GR) activity increased salinity by $16.88 \%$ and $38.31 \%$ at $150 \mathrm{mM}$ and $200 \mathrm{mM} \mathrm{NaCl}$, respectively, for salt-only trials. Addition of $\mathrm{Zn}$ increased the GR activity by $12.86 \%$ and $30.85 \%$ at $150 \mathrm{mM}$ and $200 \mathrm{mM} \mathrm{NaCl}$ treatment, respectively. 

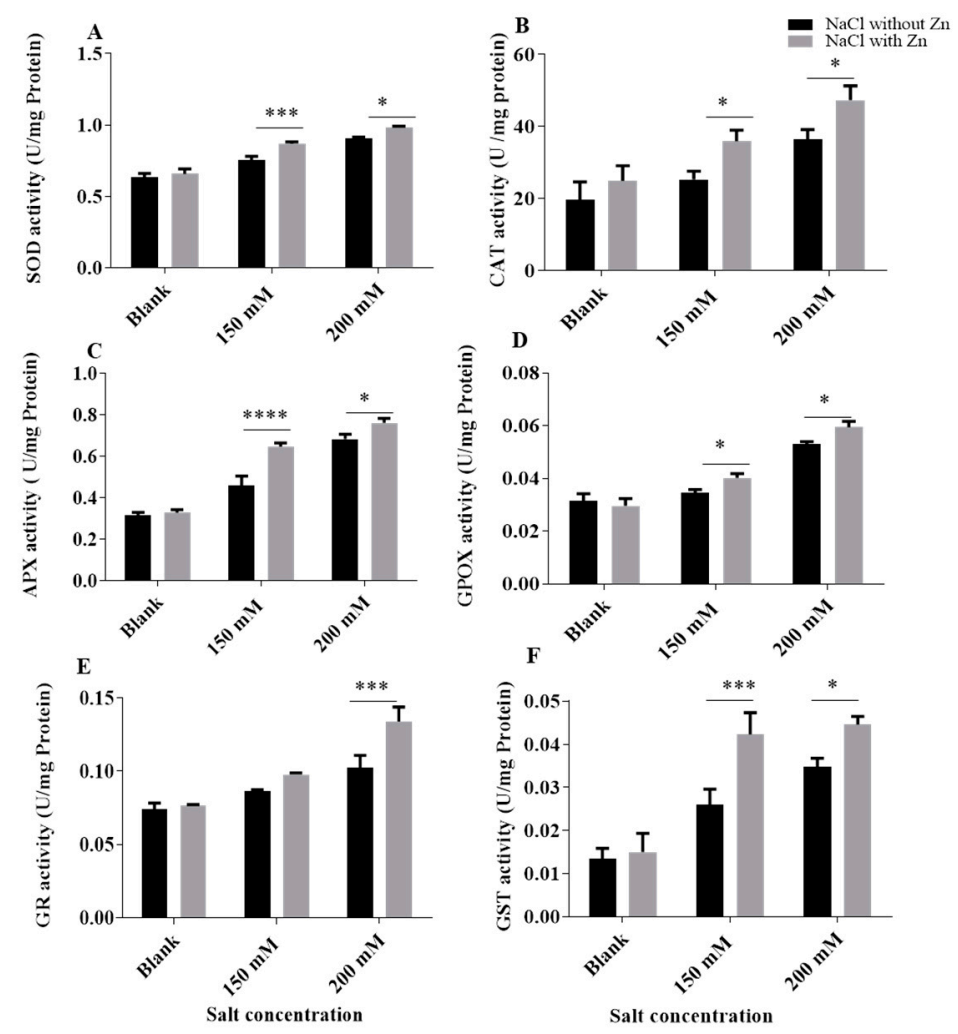

Figure 5. Effects of $\mathrm{NaCl}$ and interactive effect of $\mathrm{NaCl}$ and $\mathrm{Zn}$ on activity of (A) SOD, (B) CAT, (C) APX, (D) GPOX, (E) GR and (F) GST in mungbean. The mean values with different letters across treatments are significantly different at $p<0.05{ }^{*},{ }^{* * *},{ }^{* * * *}$ represent the significant difference between the two columns under the bar.

\section{Multivariate Data Analysis}

Multivariate data analysis was conducted to measure the interrelationship among different metabolites, antioxidant enzymes in mungbean subjected to $\mathrm{NaCl}$ and $\mathrm{NaCl}$ $+\mathrm{Zn}$ treatments. To normalize the scale of abundance, the percent difference for every metabolite was log-transformed to base 2, preceding data analysis using MetaboAnalyst software 5.0 (https:/ / www.metaboanalyst.ca, accessed on 1 May 2021). The unsupervised principal component analyses (PCA) including score plots clarify visualization of data and parallel comparison of the differentially modulated stress biomarkers in mungbeans (Figure 6A,B). Among various metabolites, proline, sugar and protein increased when subjected to $250 \mu \mathrm{M} \mathrm{Zn}+200 \mathrm{mM} \mathrm{NaCl}$ indicating that $\mathrm{Zn}$ has an alleviating effect to mitigate the $\mathrm{NaCl}$ stress besides increased proline content suggests its crucial role in combating $\mathrm{NaCl}$ stress conditions. The principal component (PC) analysis depicted in Figure 6 A,B showed that PC 1 and 2 explained $55.8 \%$ and $19.7 \%$ of the variability in the data. The angle between the vectors is an approximation of the correlation between the variables. A small angle indicates that the variables are positively correlated, an angle of 90 degrees indicates that the variables are not correlated, and an angle close to 180 degrees indicates that the variables are negatively correlated. The length of the line and its closeness to the circle indicate how well the plot represents the variable. It is, therefore, unwise to make inferences about relationships involving variables with poor representation. The covariance monoplot plots vectors pointing away from the origin to represent the original variables. The length of the line represents the variance of the variable, and the inner product between the vectors represents the covariance. A clear separation among various metabolites was found in the mungbean leaves subjected to $0 \mathrm{mM} \mathrm{NaCl}+0 \mu \mathrm{M} \mathrm{Zn} ; 250 \mu \mathrm{M} \mathrm{Zn} ; 150 \mathrm{mM}$ $\mathrm{NaCl} ; 250 \mu \mathrm{M} \mathrm{Zn}+150 \mathrm{mM} \mathrm{NaCl} ; 200 \mathrm{mM} \mathrm{NaCl} ; 250 \mu \mathrm{M} \mathrm{Zn}+200 \mathrm{mM} \mathrm{NaCl}$ treatment in PC1 and PC2 according to the above measured parameters. The correlation analysis 
showed that the activities of SOD, APX, CAT, POD, GR, GST, proline, protein, sugar, MDA and total chlorophyll content had a positive correlation in mungbean leaves (Figure 7). Heat map analysis of various metabolites and antioxidant enzymes were conducted, and it was found that the antioxidant enzymes (CAT, POD, APX, GR and GST) and metabolites (proline, protein and sugar exhibited a significant increase (as marked in yellow) while as SOD, MDA and $\mathrm{H}_{2} \mathrm{O}_{2}$ (marked in red) showed a significant decrease when subjected to $250 \mu \mathrm{M} Z \mathrm{Zn}+200 \mathrm{mM} \mathrm{NaCl}$ treatment (Supplementary Figure S2).
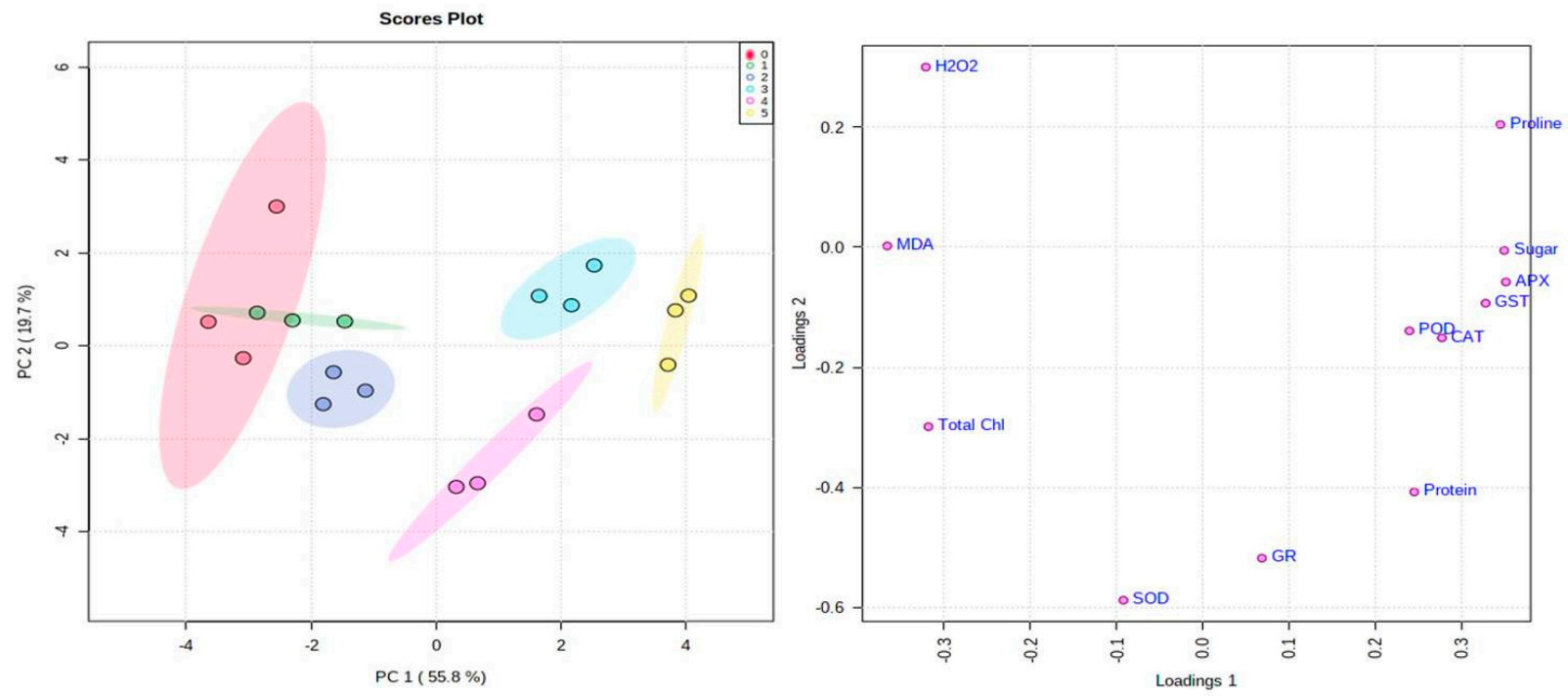

Figure 6. Effect of $\mathrm{NaCl}$ and Interactive effect of $\mathrm{NaCl}$ and $\mathrm{Zn}$ on principal component analysis (A) score plot and (B) loadings to understand the relationship among various metabolites in mungbean. The classes (0-5) in (A) refer to blank (0); Zn (1); $150 \mathrm{mM} \mathrm{NaCl}$ (2); $150 \mathrm{mM} \mathrm{NaCl}+\mathrm{Zn}$ (3); $200 \mathrm{mM} \mathrm{NaCl}$ (4); $200 \mathrm{mM} \mathrm{NaCl}+\mathrm{Zn}$ (5).

2.5. Effect of Salt and Salt with Zn on PAL (Phenylalanine Ammonia-Lyase) and TAL (Tyrosine Ammonia-Lyase)

PAL activity was increased by $96.02 \%$ and $88.58 \%$ at $150 \mathrm{mM}$ and $200 \mathrm{mM} \mathrm{NaCl}$, respectively, for salt-only trials and application of $\mathrm{Zn}$ further enhanced it by $78.48 \%$ and $98.68 \%$ at $150 \mathrm{mM}$ and $200 \mathrm{mM} \mathrm{NaCl}$ treatment, respectively. TAL activity was increased by $96.02 \%$ and $88.58 \%$ at $150 \mathrm{mM}$ and $200 \mathrm{mM} \mathrm{NaCl}$, respectively, for salt-only trials and application of $\mathrm{Zn}$ further enhanced it by $104.08 \%$ and $109.83 \%$ at $150 \mathrm{mM}$ and $200 \mathrm{mM}$ $\mathrm{NaCl}$ treatment, respectively (Figure 8).

2.6. Effect of Salt and Salt with Zn on TP (Total Phenol), TF (Total Flavonoid), TRP (Total Reducing Power), DPPH (2,2-Diphenyl-1-Picrylhydrazyl) and FRAP (Ferric Reducing Antioxidant Power Assay)

The total phenol content of seedlings was increased by $14.71 \%$ and $21.57 \%$ at $150 \mathrm{mM}$ and $200 \mathrm{mM} \mathrm{NaCl}$, respectively, for salt-only trials. Application of $\mathrm{Zn}$ further enhanced it by $19.54 \%$ and $17.78 \%$ at $150 \mathrm{mM}$ and $200 \mathrm{mM} \mathrm{NaCl}$ treatment, respectively (Figure 9). The total flavonoid content showed the same trend as total phenol; it increased by $83.14 \%$ and $133.70 \%$ at $150 \mathrm{mM}$ and $200 \mathrm{mM} \mathrm{NaCl}$, respectively, for salt-only trials. Application of $\mathrm{Zn}$ further increased by $36.84 \%$ and $37.80 \%$ at $150 \mathrm{mM}$ and $200 \mathrm{mM} \mathrm{NaCl}$ treatment, respectively. The total reducing power was increased by $13.23 \%$ and $63.71 \%$ at $150 \mathrm{mM}$ and $200 \mathrm{mM} \mathrm{NaCl}$, respectively, for salt-only trials. Zn application further increased it by $109.52 \%$ and $8.51 \%$ at $150 \mathrm{mM}$ and $200 \mathrm{mM} \mathrm{NaCl}$ treatment, respectively. DPPH was increased by $15.10 \%$ and $37.76 \%$ at $150 \mathrm{mM}$ and $200 \mathrm{mM} \mathrm{NaCl}$, respectively, compared to control, and $\mathrm{Zn}$ application further increased it by $13.49 \%$ and $9.75 \%$ at $150 \mathrm{mM}$ and $200 \mathrm{mM} \mathrm{NaCl}$ treatment, respectively. FRAP was increased by $56.33 \%$ and $100.22 \%$ at $150 \mathrm{mM}$ and $200 \mathrm{mM} \mathrm{NaCl}$, respectively, compared to control, and $\mathrm{Zn}$ further increased it by $59.87 \%$ and $58.06 \%$ at $150 \mathrm{mM}$ and $200 \mathrm{mM} \mathrm{NaCl}$ treatment, respectively (Figure 9). 


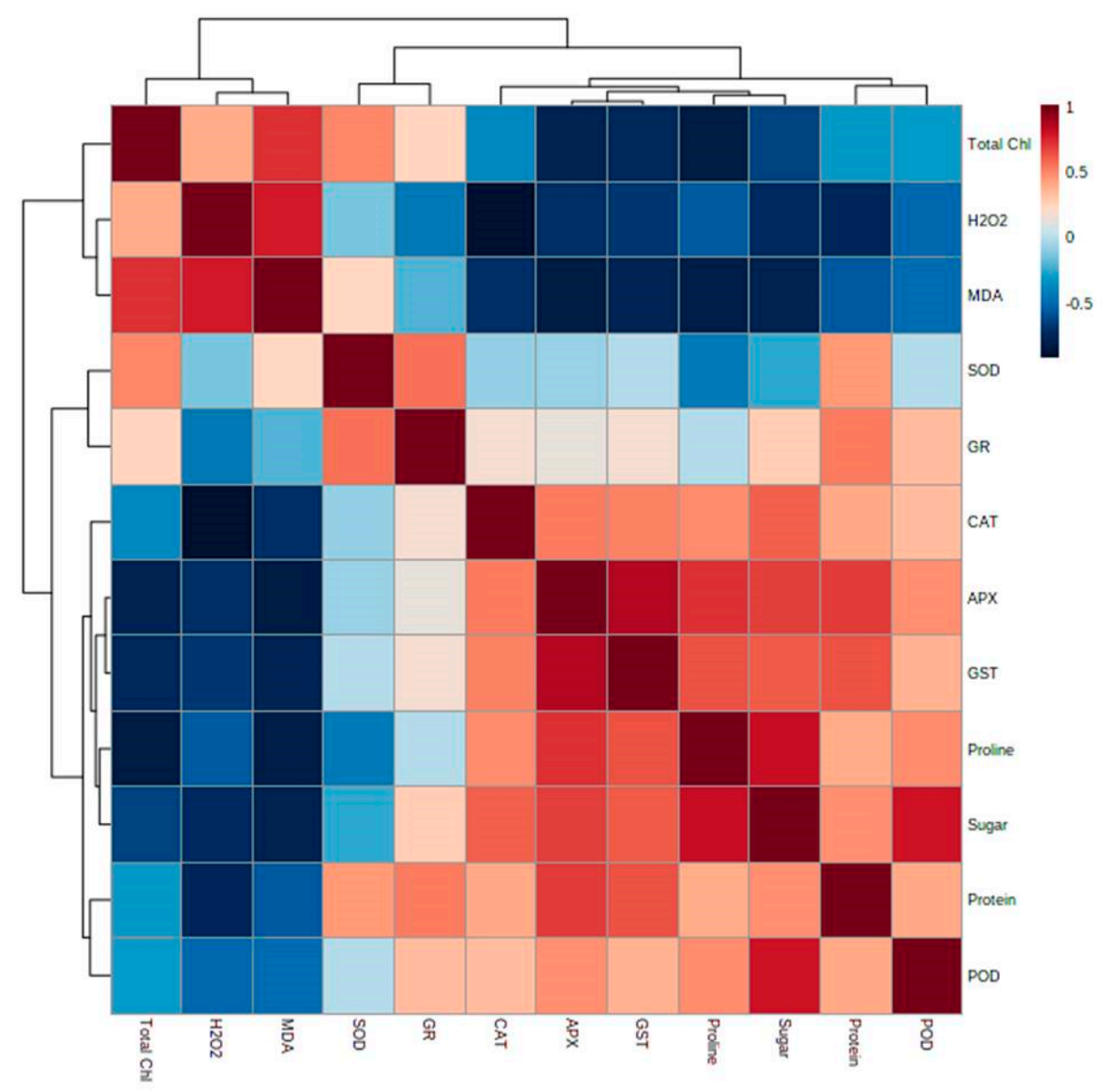

Figure 7. Effects of $\mathrm{NaCl}$ and interactive effect of $\mathrm{NaCl}$ and $\mathrm{Zn}$ on correlation analysis among the various physiological parameters of total chlorophyll (Total Chl). hydrogen peroxide $\left(\mathrm{H}_{2} \mathrm{O}_{2}\right)$, lipid peroxidation (MDA), proline, protein, sugar, superoxide dismutase (SOD), catalase (CAT), ascorbate peroxidase (APX), guaiacol peroxidase (POD), glutathione reductase (GR) and glutathiones-transferase (GST) in mungbean. Pearson's correlation coefficient among data was analyzed using $R$ scripts. The maroon color (1) indicates strong positive correlation among metabolites whereas blue $(-0.5)$ indicates negative correlation among the metabolites.

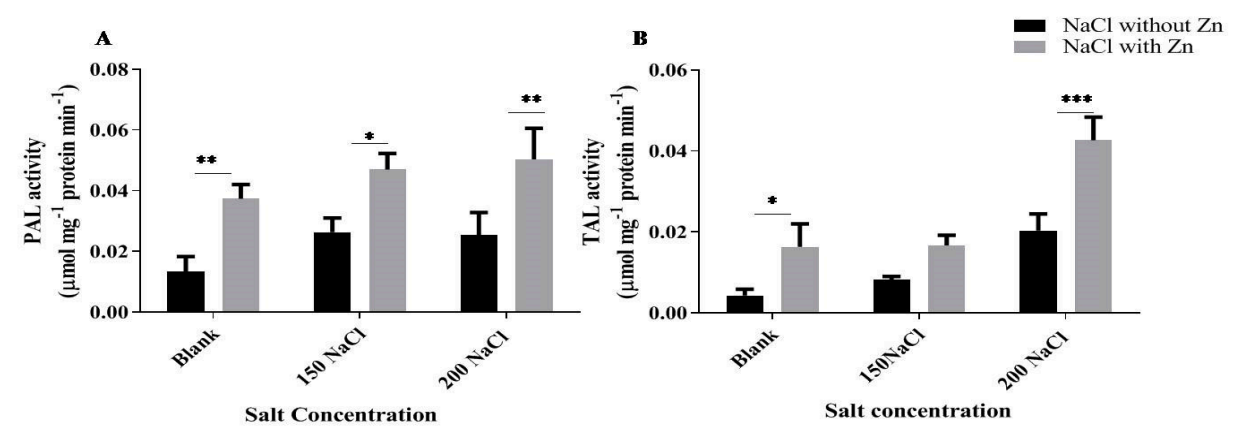

Figure 8. Effects of $\mathrm{NaCl}$ and interactive effect of $\mathrm{NaCl}$ and $\mathrm{Zn}$ on (A) phenylalanine ammonia-lyase and (B) tyrosine ammonia-lyase. Values represent mean $\pm \mathrm{SD}, \mathrm{n}=3$. The mean values with different letters across treatments are significantly different at $p<0.05 ;{ }^{*},{ }^{* *},{ }^{* *}$ represent the significant difference between the two columns under the bar. 


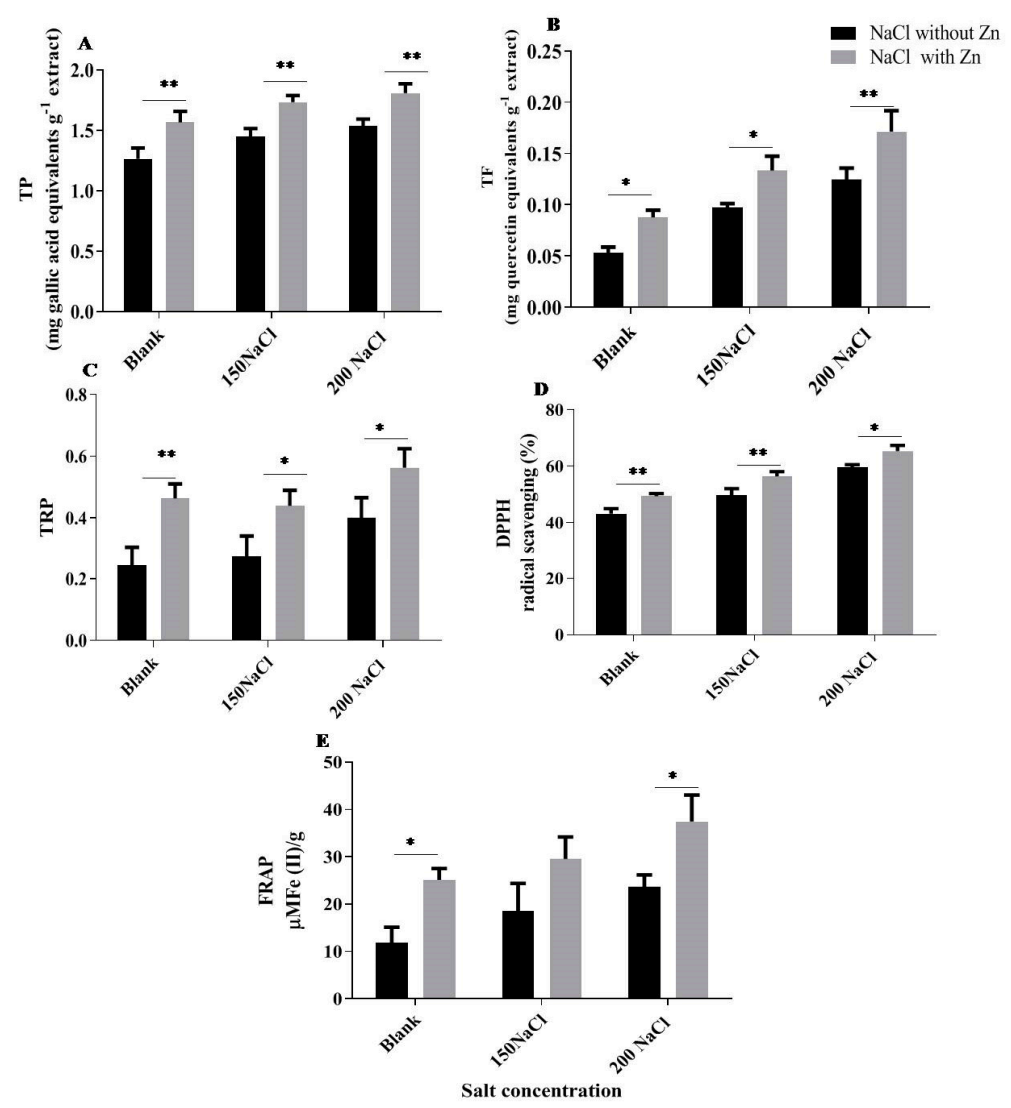

Figure 9. Effects of $\mathrm{Zn}$; (A) total phenol, (B) total flavonoid content, (C) total reducing power, (D) DPPH and (E) FRAP antioxidant assays in mungbean. The mean values with different letters across treatments are significantly different at $p<0.05 . *{ }^{* *}$ represent the significant difference between the two columns under the bar.

\section{Discussion}

In plants, salt stress induces hyper-osmotic and hyper-ionic stress, ion toxicity (particularly caused by $\mathrm{Cl}^{-}$) in addition to dehydration [27]. Salinity poses deleterious effects on the photosynthesis process ranging from changes in pigment composition, restricted $\mathrm{CO}_{2}$ diffusion into the chloroplast, limitations on stomatal opening mediated by shootroot-generated hormones and on the mesophyll transport of $\mathrm{CO}_{2}$, to alterations in leaf photochemistry and carbon metabolism [28]. Worldwide salinity is one of the major environmental limitations that significantly inhibit crop productivity, and the present study was executed to analyze the effect of $\mathrm{Zn}$ on the different mechanisms to combat $\mathrm{NaCl}$ toxicity in mungbean. Zn plays a key role in mediating different cellular functions [29]. The interaction of a micronutrient with a stressor is important for investigating, consideration and ultimately in refining plant defense strategies through various factors. In the current study, exogenously applied Zn showed a strong constructive association with key morphological and physiological components in mungbean under salinity. Noticeable changes were observed in fresh and dry weights as both declined due to salinity and Zn treatment alleviate the same (Figure 1). Our findings are in accordance with the previous study on salt-stressed moringa where a decrease in plant height, root length, branch number, fresh and dry weight of roots and shoots was observed [30,31].

Salinity stresses induce disturbances in chloroplast photochemistry. When the rate of absorption of light energy by photosynthetic pigments exceeds the rate of its consumption, the absorbed light energy accelerates the process of photoinhibition and decreased photosynthetic ability under salt stress [28]. Photosynthetic ability of plants also decreases due to the suppression of chlorophyll synthesis or decrease in the absorption of minerals 
needed for chlorophyll biosynthesis, which increased on zinc application and successively, increases plant height and yield, thereby playing a crucial role in biomass production.

In the current study, exogenous application of zinc showed pronounced increases in growth framework, i.e., length of root and shoot, fresh and dry weight. Similar, results were shown in cotton plants where zinc as nano-fertilizer showed increased growth in comparison to salt-treated plants [32]. In this study, salinity reduces the relative water content under salt stress (Figure 1E). It is believed that under salt stress, increased salt concentration hampers water uptake through the root [1]. According to Hafeez et al. [33], salinity induces loss of turgor due to decreased RWC, which obstruct the cell elongation process. Water deficiency might be collapsing all metabolic processes in the seedlings in saline conditions impeding their ability to grow in such conditions but zinc supplementation aids in survivability and helped in overcoming the effect of salinity. Our results are following Galal [34], who observed a decrease in RWC in Hibiscus sabdariffa L. suggesting it be amongst the important index of salt tolerance. Our results are also in accordance with Weisany et al. [29], suggesting the role of $\mathrm{Zn}$ in alleviating salt stress by positively regulating uptake as well as transport of water.

In the current study, salt stress results in a decrease of total chlorophyll in mungbean leaves (Figure 2), which is in accordance with the results of Alharby et al. [26], Weisany et al. [35], Hayat et al. [36], Iqbal et al. [37] and Ahmad et al. [38], in various plant species. Salinity obstructs the functioning of important enzymes responsible for the synthesis of photosynthetic pigments [39]. The modulation or destruction of these enzymes induces the chlorophyllase, responsible for chlorophyll degradation and ultimately reduced chlorophyll content [40]. While the $\mathrm{Zn}$ is believed to positively regulate magnesium transport, an important component of chlorophyll structure and hence results in increased chlorophyll content [35,41]. Increased chlorophyll contents are due to zinc which acts as a structural and catalytic component of proteins, enzymes and as a co-factor for the normal development of pigment biosynthesis [42].

Our results are in accordance with results in Vigna radiate [42] and in B. juncea [42] where chlorophyll increased with exogenous $\mathrm{Zn}$ application. The amelioration by $\mathrm{Zn}$ of declined chlorophyll which happened during salt stress might be due to zinc-induced shielding of the sulfhydryl group [35].

Salinity also induces a cascade of oxidative reaction resulting in the overproduction of ROS (Figure 3). Membranes are the main site of ROS attack which leads to severe lipid peroxidation, dimerization and polymerization of proteins, causing alteration of cell membranes [43].Under salinity, lipid peroxidation is a manifestation of damage and leakage of membranes [34,44]. In the current study, lipid peroxidation was evident under salt stress by increased ion leakage, TBARS content and $\mathrm{H}_{2} \mathrm{O}_{2}$ content. The increased ion leakage is associated with lipid peroxidation leading to membrane damage [45] and maintaining membrane integrity is considered a primary part of the salinity tolerance mechanism [46,47]. Our results are in accordance with the findings of Weisany et al. [29] and Rasool et al. [45]. The addition of zinc along with the salt mitigated deleterious effects of salt i.e., electrolyte leakage, TBARS content and $\mathrm{H}_{2} \mathrm{O}_{2}$ content declined significantly. It has been suggested that zinc alleviates membrane damage by maintaining its permeability to its proper range [48]. Zinc has a regulatory role on the $\mathrm{Na}^{+}$and $\mathrm{Cl}^{-}$uptake and translocation rate. So, in the salt-affected soils, zinc application could abate possible $\mathrm{Na}^{+}$and $\mathrm{Cl}^{-}$injuries such as ROS production and lipid peroxidation in the plant. The decrease in $\mathrm{H}_{2} \mathrm{O}_{2}$ was achieved upon $\mathrm{Zn}$ supplementation to seedlings growing with salt. Similar results were seen in salt-stressed eggplant where $\mathrm{Zn}$ lowered the $\mathrm{H}_{2} \mathrm{O}_{2}$ content [49]. Zinc-treated mungbean seedlings exhibited reduced TBARS and increased membrane stability, which validates the positive role of $\mathrm{Zn}$ in evading ROS-induced oxidative damage during salt stress. The results are parallel with the results of Brassica juncea under salt stress [38].

Osmolytes accumulates in response to salinity, wherein the accumulation of proline is a common metabolic process [50] (Figure 4). In the current study, increased proline accumulation was recorded on exposure to $\mathrm{NaCl}$. These results are concomitant with the findings 
which reveal that extent of proline accumulation has a positive association/correlation with $\mathrm{NaCl}$ concentrations [51-53]. It is believed that salinity results in stomatal closure, which limits both the fixation of $\mathrm{CO}_{2}$ during photosynthesis as well as carbon reduction by the Calvin cycle. The decreased carbon reduction leads to the unavailability of $\mathrm{NADP}^{+}$for electron acceptance so $\mathrm{NADPH}_{2}$ donates an electron to glutamate for proline biosynthesis and regenerates $\mathrm{NADP}^{+}$for further electron acceptance [54,55]. The application of $\mathrm{Zn}$ further increased proline accumulation in salt-treated mungbean. Proline offers an important tolerance strategy by maintaining tissue water potential under environmental stresses including salinity [56-58]. Higher proline content in salt-stressed plants is maintained by increased activity of key enzymes involved in proline synthesis [59]. Proline protects the enzymatic function of different antioxidant enzymes and helps in free radical scavenging [60].

An enzymatic antioxidant system (SOD, POD, CAT, APX, GR AND GST) protects plants against oxidative damage of salinity [61-63] (Figure 5). Zinc also resulted in increased antioxidant enzyme activities. Increased SOD activity enables detoxification of more $\mathrm{O}^{2-}$ to $\mathrm{H}_{2} \mathrm{O}_{2}$, which is further detoxified to $\mathrm{H}_{2} \mathrm{O}$. The conversion of $\mathrm{H}_{2} \mathrm{O}_{2}$ to $\mathrm{H}_{2} \mathrm{O}$ can be catalyzed by enzymes, such as CAT, APX and POX, which are also enhanced under $\mathrm{Zn}$ treatment. In the current study, the antioxidant enzyme activity significantly increases under salinity and this incline was even furthered with $\mathrm{Zn}$ treatment. The potential of tolerance against salinity in plants is determined by its antioxidant system [61]; as in our study, plants treated with $\mathrm{Zn}$ and salt had an efficient antioxidant system compared to salttreated plants. Our results corroborate with the findings in maize [64] where Zn application stimulates antioxidant enzyme activities to protect plants from oxidative damage. Similarly, Ahmad et al. [38] found out zinc to be beneficial in alleviating salt stress in Brassica Juncea. SOD is the first line of defense opposing ROS and scavenges $\mathrm{O}_{2-}$. In the current study, the activity of SOD increased significantly during salt stress which is in accordance with the results in Setaria italica [45] and Panicum milliaceum [53]. Zn further amplified the SOD activity to alleviate the deleterious effect of salinity, which is in accordance with the findings in pistachio [65], sunflower [66] and eggplant [49] where $\mathrm{Zn}$ supplementation enhanced the SOD activity. Catalase scavenges $\mathrm{H}_{2} \mathrm{O}_{2}$ by converting $\mathrm{H}_{2} \mathrm{O}_{2}$ into $\mathrm{H}_{2} \mathrm{O}$ and $1 / 2 \mathrm{O}_{2}$. In the current study, catalase activity increased in response to salinity and the addition of $\mathrm{Zn}$ further enhanced its activity, suggesting CAT elevation by $\mathrm{Zn}$ for improving $\mathrm{H}_{2} \mathrm{O}_{2}$ scavenging during stress. Our results are following Mallik et al. [67], where CAT activity increased in salt-tolerant plants under different salt treatments. They also suggest that under high salinity, various new isoforms of CAT are formed. Our finding with CAT is in accordance with the findings of Mittova et al. [68] in tomato. Zn supplementation further increased the CAT activity in salt-treated plants which is in accordance with the results of mustard [38]. Wani et al. [69] suggested that $\mathrm{Zn}$ is indirectly responsible for the increased activity of enzymes involved in eliminating $\mathrm{H}_{2} \mathrm{O}_{2}$. APX is another important enzyme that also has a pivotal role in $\mathrm{H}_{2} \mathrm{O}_{2}$ detoxification and concentration modulation in different cellular organelles [70]. In the current study, the activity of APX inclined in response to salt and Zn supplementation further stimulated the APX activity in the salt-treated mungbean plants. Our findings are in accordance with those obtained by $\mathrm{Ab}$ bas [71], who suggested that increased APX activity might be due to increased $\mathrm{H}_{2} \mathrm{O}_{2}$ levels. Amiri et al. [65] also reported increased APX enzyme activity in $\mathrm{Zn}$ supplemented plants. Cakmak [72] suggested that $\mathrm{Zn}$ can facilitate the biosynthesis of antioxidant enzymes and alleviate the stress. Another important antioxidant enzyme is GST, which detoxifies xenobiotic compounds by mediating their binding to non-enzymatic antioxidants, such as tripeptide glutathione [10,73]. In this study, the activity of GST increases during salt stress and the Zn supplementation further enhanced the GST activity. Zn induced GST is responsible for rapid scavenging of radicals and has an important part in hormone homeostasis, stress responses and cell apoptosis $[10,74]$ Our results showing increased GST activity are in agreement with the results of salt-stressed Brassica juncea [38] and in Lycopersicon esculentum [75]. 
POD catalyzes the reduction of $\mathrm{H}_{2} \mathrm{O}_{2}$ to water, and the presence of these enzymes has been established in several organisms including plants [76]. The POD activity in mungbean seedlings increased with increasing salinity as well as zinc supplementation. Our results are in coherence with Triticum aestivum [77]. It was exhibited in Oryza sativa that the expression of POD genes was obligatory for redox homeostasis [78,79]. Zn supplementation further enhanced the POD activity which is in agreement with the findings of salt-stressed O. sativa [80]. Another important antioxidant enzyme is GR, which has an essential role in protection against ROS through reduction of GSH $[10,81,82]$. Glutathione reductase (GR) is avital component of ascorbate-glutathione (AsA-GSH) cycle, which has a significant role in protection from ROS [83]. In the current study, the activity of GR increased during salt stress and Zn application significantly increased GR activity in wheat plants [84].

Further, the first principal component axis (PCA1) extracted $55.8 \%$ of variance for the total values of physiological change under $\mathrm{NaCl}$ stress in leaf samples of Vigna radiata. SOD, CAT, GR and protein had the highest contribution to the first axis. The second PC axis (PCA2) had lower significance (19.7\% of variance) under salt stress and was mostly determined by the contributions of stress biomarkers. The length and direction of the vectors indicate the strength of the vector effect and correlation between vectors. Long vectors for all our parameters indicate that the vector greatly affected the results of the analysis. The cumulative percentage of PCA1 and PCA2 was 75.5\% (Figure 6A,B). It was clear that the SOD, CAT, GR and protein grouped together with positive loading on the right lower side of the biplot, suggesting that these parameters are positive correlated with each other (Figure 7). Proline was observed on the right upper side of the biplot, while $\mathrm{H}_{2} \mathrm{O}_{2}$ and MDA were on the left upper portion of the biplot. The angles between different antioxidants are small, indicating that these parameters are positively correlated. On the biplot, sugar, APX segregate in opposite directions, indicating these factors are negatively correlated.

Salt stress leads to ROS's overproduction [85] and requires the activation of a wellorchestrated antioxidant defense system to prevent ROS proliferation [86-88]. Phenolic compounds help in scavenging ROS under salinity stress [89,90]. The phenyl-propanoid biosynthetic pathway is central in forming different phenolic compounds [90,91]. Phenylalanine ammonium-lyase is a critical enzyme in the phenylpropanoid pathway and recognized as a marker of various abiotic stresses in different plant species [92]. It is an important enzyme that links primary and secondary (phenyl-propanoid) metabolism [92]. Salinity stress significantly affected PAL enzyme activity(Figure 8A), similar to results observed in chamomile herb under salt and heavy metal stress, where plants showed increased PAL activity after salt stress [93]. Exogenous application of $\mathrm{Zn}$ further improved the PAL activity to alleviate the deleterious effects of salinity. Our results are in correspondence with the finding of Luoet al. [94], where $2 \mathrm{mM}$ Zn increased the PAL activity by $140 \%$ compared to control and are speculated to impart resistance to stress conditions [94]. PAL has been generally recognized as a marker of environmental stress in different plant species. Their increased activity is a typical response against biotic and abiotic stresses in plants, which stimulates secondary metabolite production. PAL and TAL are important enzymes of biosynthetic pathway of phenolic compounds. Phenolic compounds such as non-enzymatic antioxidants act as electron quenchers and are involved in suppression of ROS to alleviate the deleterious effects of salinity [93,95-97]. The present investigation revealed that the specific activity of TAL also increased with salt and Zn application (Figure 8B). Our results are in accordance with the findings of cluster bean where specific activity of TAL doubled after $\mathrm{Zn}$ treatment [98]. It is noteworthy to mention that $\mathrm{Zn}$ acts as a cofactor for PAL and TAL enzymes and therefore, these enzymes' activities might have up-regulated after exogenous application of $\mathrm{Zn}$.

Phenolic compounds play an essential role in scavenging excess ROS, notably phenolic acids and flavonoids assume a significant role. The present study observed that $\mathrm{NaCl}$ increased phenolic acids and flavonoids as a defense response in mungbean (Figure 9A,B) which corroborates with the study of Amaranth, where phenolic acids and flavonoids in- 
creased in response to salt stress [99]. However, in this study, we observed that upon applying exogenous $\mathrm{Zn}$, the antioxidant activity increased as observed in pistachio [44]. Phenolic content increased after $\mathrm{Zn}$ application compared to salt treatment alone, with a maximum increase at $20 \mathrm{mg} \mathrm{Zn} \mathrm{kg}^{-1}$ of soil [44]. Plants generally differ in their phenolic contents as genetic makeup and environment play an essential factor [100]. Phenolics enhance cell antioxidative capacity by inactivating free radicals and free radical generation by averting hydroperoxides' decay [101,102]. Salt stress increases phenolic production to detoxify the ROS [103]. An improvement in the production of total phenol by exogenous application of Zn may be attributed to the development of nonstructural carbohydrate, enhancement in photosynthesis and proper translocation of photosynthate $[104,105]$. Flavonoids are low molecular weight polyphenols, which protect photosynthesizing cells and are involved in scavenging superoxide radicals, improving photosynthesis. In our study, the flavonoid content increased after salinity exposure. Similar results were found in Japanese catnip, where its content enhanced by low and moderate salinity levels but was constrained by higher levels [106]. Specific transcription factors associated with flavonol biosynthesis [107] are produced due to fluctuations in redox potential, and flavonol can serve as antioxidants in response to environmental stresses, including salinity stress [108,109]. Zn's application $(300 \mu \mathrm{M})$ further increased flavonoid content, but $\mathrm{Zn}$ 's role in enhancing the flavonoid content is still unclear. However, $\mathrm{Zn}$ acts as a chelator under salt stress [110], thus protecting the plant from ROS. Our results agree with the study on brown mustard, where it was found that Zn application increased phenol and flavonoid content [38]. The DPPH method is one of the effective methods for assessing the concentration of radical-scavenging. In mungbean, the increase in DPPH content was observed with an increase in salt concentration(Figure 9D), as observed in the study of sunflower callus extracts, where $300 \mathrm{mM} \mathrm{NaCl}$ concentration increased DPPH content by almost 1.12 times compared to control [111]. Zn addition further increased the DPPH content. DPPH activity under salt-treated is high because of phenolic compounds in higher amounts [112]. Another factor for increased activity of DPPH might be an increased amount of flavonoids $[111,113,114]$. Our results agree with the study on tobacco, where $0.24 \mathrm{mM} \mu \mathrm{P}-\mathrm{ZnO}$ treatment showed significant inductions on the DPPH scavenging activity to control [115]. Moreover, salinity significantly enhanced the FRAP activity under salinity stress (Figure 9E), as reported in strawberries under salinity stress [116]. Our results showed a significant increase in FRAP with the application of $\mathrm{Zn}$. Phenolic compounds have redox properties and act as hydrogen donators and singlet oxygen quenchers [117]. The redox potential of phenolic compounds helps in determining antioxidant potential. FRAP examines the reducing capability of an antioxidant with a ferric tripyridyltriazine complex and producing a shaded ferrous tripyridyltriazine.

\section{Materials and Methods}

\subsection{Growth and Stress Conditions}

This study is focused on the NCM-1 (NARC-Islamabad) genotype of mungbean (Vigna radiata (L.) Wilczek) and its seeds were procured from the Pakistan Agriculture Research, Islamabad. The seeds were soaked in $5 \% \mathrm{NaOCl}$ solution for $10 \mathrm{~min}$ for sterilization. After sterilization, seeds were sown in plastic pots $(22 \mathrm{~cm}$ diameter) containing $3 \mathrm{~kg}$ of moist acid-washed autoclaved sand. For nutrition, seedlings were supplemented with Hoagland's nutrient medium of pH 6.5 [118]. These were grown under controlled conditions with $28 \pm 1.5^{\circ} \mathrm{C}$ at daytime and $22 \pm 1.5^{\circ} \mathrm{C}$ at nighttime, with a relative humidity of $60-70 \%$. The treatments were started succeeding germination on the 21 st day by making solutions in Hoagland's medium to obtain the final concentration of $150 \mathrm{mM}$ and $200 \mathrm{mM}$ for $\mathrm{NaCl}$ and $250 \mu \mathrm{M}$ for $\mathrm{Zn}$, respectively (Supplementary Figure S1). Zn (250 $\mu \mathrm{M}$ ) concentration was selected based on the tolerance index of $\mathrm{Zn}$ treatments ranging from $50 \mu \mathrm{M}$ to $600 \mu \mathrm{M}$. Ten replicates were randomly used to determine growth parameters and three replicates were used for the biochemical and enzymatic analysis. Morphological parameters such as length, height, fresh and dry weight of roots and shoots were taken by measuring ten plants collected randomly. Weighing of material was performed individually 
for taking fresh weights (FW) followed by drying process for $72 \mathrm{~h}$ at $70{ }^{\circ} \mathrm{C}$ and finally, the dry weight (DW: biomass accumulation) was recorded by a precision balance. For calculating relative water content (RWC), the ten plants were weighed for fresh weight, and then these plants were placed in $\mathrm{ddH}_{2} \mathrm{O}$ for $24 \mathrm{~h}$ at $4{ }^{\circ} \mathrm{C}$ and weighed for turgid/swelled weight (SW) and finally, these plants were allowed to dry for $72 \mathrm{~h}$ at $70{ }^{\circ} \mathrm{C}$ and again weighed for the dry weight (DW). The values of FW, SW and DW from all treatments were used in the following equation.

$$
\mathrm{RWC}(\%)=[(\mathrm{FW}-\mathrm{DW}) /(\mathrm{SW}-\mathrm{DW})] \times 100
$$

\subsection{Estimation of Photosynthetic Pigments}

The photosynthetic pigments chlorophylls (Chla: $\mathrm{C}_{55} \mathrm{H}_{72} \mathrm{O}_{5} \mathrm{~N}_{4} \mathrm{Mg}$, Chlb: $\mathrm{C}_{55} \mathrm{H}_{70} \mathrm{MgN}_{4} \mathrm{O}_{6}$ ) and carotenoids in fresh leaves were determined as described by the Lichtenthaler method [119]. The absorbance was recorded at $663 \mathrm{~nm}, 645 \mathrm{~nm}$ and $480 \mathrm{~nm}$ for chl a, $\mathrm{chl} \mathrm{b}$ and carotenoids using Shimadzu UV-vis- spectrophotometer-1800 Japan and their quantities were indicated as $\mathrm{mg} \mathrm{g}^{-1} \mathrm{FW}$.

\subsection{Estimation of Membrane Stability Index (MSI)}

The Tabot and Adams [120] method was followed for estimating electrolyte leakage percentage (ELP) or membrane stability index (MSI). Leaves sterilized 3 times with distilled water were cut into $1-\mathrm{cm}^{2}$ sections and placed in stoppered vials with $10 \mathrm{~mL}$ distilled water. The vials were placed in a water bath at $40^{\circ} \mathrm{C}$ for $30 \mathrm{~min}$ followed by recording the initial electrical conductivity of the solution (EC1). The vials were now subjected in a water bath to boiling temperature for 10 $\mathrm{min}$ and then allowed to cool for recording the final electrical conductivity (EC2). The initial (EC1) and final (EC2) values were used for calculating ELP by the equation: $[1-(E C 1 / E C 2)] \times 100$. The recordings were taken by using an electrical conductivity meter and ELP values indexed the changes in the permeability of cell membranes.

\subsection{Determination of Lipid Peroxidation (LPO) Rate}

Lipid peroxidation rate was assessed by evaluating the amount of total 2-thiobarbituric acid reactive substances (TBARS) and revealed as equivalents of malondialdehyde (MDA). TBARS was assessed by method of Cakmak and Horst [121]. The absorbance was taken at $532 \mathrm{~nm}$ and $600 \mathrm{~nm}$ and the MDA-TBA complex computed using extinction coefficient $155 \mathrm{mM}^{-1} \mathrm{~cm}^{-1}$, and were, finally, expressed as nmol MDA $\mathrm{g}^{-1} \mathrm{FW}$.

\subsection{Determination of Hydrogen Peroxide $\left(\mathrm{H}_{2} \mathrm{O}_{2}\right)$ Content}

Hydrogen peroxide $\left(\mathrm{H}_{2} \mathrm{O}_{2}\right)$ content was assessed following the protocol of Velikova et al. [122] where frozen tissues (70 mg leaf) were coalesced in $5 \mathrm{~mL}$ of $0.1 \%$ $(\mathrm{w} / \mathrm{v})$ trichloroacetic acid (TCA) under ice-cold conditions. The coalesced mixture was centrifuged for $15 \mathrm{~min}$ at $12,000 \mathrm{rpm}$. To the $0.5 \mathrm{~mL}$ supernatant, $0.5 \mathrm{~mL}$ of $10 \mathrm{mM}$ potassium phosphate buffer $(\mathrm{pH} 7)$ and $1 \mathrm{~mL}$ of $1 \mathrm{M} \mathrm{KI}$ were added, and readings were taken at $390 \mathrm{~nm}$.

\subsection{Estimation of Osmolytes}

The osmolytes were assessed by methods: total soluble sugar (TSS) by Dey [123] free proline content by Bates et al. [124].The total soluble protein (TSP) was measured spectrophotometrically at $595 \mathrm{~nm}$, using bovine serum albumin (BSA) standard following Bradford [125].

\subsection{Enzymatic Assays}

Fresh leaf tissue (200 mg) coalesced under chilled conditions with $3 \mathrm{~mL}$ extraction buffer (50 mM phosphate buffer $\mathrm{pH} 7.8 ; 1 \mathrm{mM}$ EDTA-Na $\mathrm{N}_{2} ; 1 \% \mathrm{PVP}$ ) in mortar and pes- 
tle. The coalesced mixture was centrifuged for half an hour at $13,000 \mathrm{rpm}$ at $4{ }^{\circ} \mathrm{C}$. The supernatant obtained was used for performing antioxidant enzyme assays.

\subsubsection{Determination of Superoxide Dismutase (SOD) Activity}

The superoxide dismutase (SOD) activity was assessed according to its ability to inhibit photochemical reduction of nitro blue tetrazolium (NBT) [126] with slight modifications. The absorbance was measured at $560 \mathrm{~nm}$ against a blank using a UV-visible spectrophotometer and expressed as $\mathrm{Umin}^{-1} \mathrm{mg}^{-1}$ protein.

\subsubsection{Determination of Catalase (CAT) Activity}

Catalase (CAT) activity was assessed by the method described by Aebi [127]. This assay is based on decreased absorbance of $\mathrm{H}_{2} \mathrm{O}_{2}$ taken at $240 \mathrm{~nm}$ and activity computed using the extinction coefficient $0.036 \mathrm{mM}^{-1} \mathrm{~cm}^{-1}$ and expressed as $\mathrm{Umin}^{-1} \mathrm{mg}^{-1}$ protein.

\subsubsection{Determination of Ascorbate Peroxidase (APX) Activity}

Ascorbate peroxidase (APX) activity was assessed according to protocol by Nakano and Asada [128]. The enzyme activity was computed using extinction coefficient $2.8 \mathrm{mM}^{-1} \mathrm{~cm}^{-1}$ and, later, expressed as Umin ${ }^{-1} \mathrm{mg}^{-1}$ protein.

\subsubsection{Determination of Guaiacol Peroxidase (POD/GPOX) Activity}

Guaiacol peroxidase (POD/GPOX) activity was assessed using guaiacol. Absorbance was recorded continually for the $90 \mathrm{~s}$ at $470 \mathrm{~nm}$ and enzyme activity was represented as an absorption unit per minute per $\mathrm{mg}$ protein $\left(\mathrm{Umin}^{-1} \mathrm{mg}^{-1}\right.$ protein) and activity was computed using the extinction coefficient of $26.6 \mathrm{mM}^{-1} \mathrm{~cm}^{-1}$.

\subsubsection{Determination of Glutathione-s-Transferase (GST) Activity}

Glutathione-s-transferase (GST) activity was assessed following the protocol by Habig and Jacoby [129]. The absorbance was recorded at $340 \mathrm{~nm}$ and the activity computed using extinction coefficient $9.6 \mathrm{mM}^{-1} \mathrm{~cm}^{-1}$ and, finally, represented as unit per minute per $\mathrm{mg}$ protein $\left(\mathrm{Umin}^{-1} \mathrm{mg}^{-1}\right.$ protein).

\subsubsection{Determination of Glutathione-Reductase (GR) Activity}

Estimation of glutathione reductase (GR) was performed by the method of Foyer and Halliwell [130] by following decreased absorbance at $340 \mathrm{~nm}$ due to NADPH oxidation $\left(\mathrm{E}=6.2 \mathrm{mM}^{-1} \mathrm{~cm}^{-1}\right)$ and, finally, represented as unit per minute per mg protein (Umin ${ }^{-1} \mathrm{mg}^{-1}$ protein).

\subsection{Determination of Antioxidant Activity}

Plants were collected from each treatment randomly and carefully washed with deionized water three times to remove sand from the surface of the roots; root length and shoot length was measured with the help of a ruler. Then the plant material was shade dried and then powdered and was stored in airtight bags until use. Next, $5 \mathrm{~g}$ of stored dried powder of leaf material was extracted with methanol using a shaker for $24 \mathrm{~h}$ at room temperature. The macerate was then filtered using Whatman's filter paper. This supernatant was kept in airtight tubes and kept at $4{ }^{\circ} \mathrm{C}$ until further use.

\subsubsection{Determination of PAL and TAL Activity}

The leaf material $(0.5 \mathrm{~g})$ was homogenized in $3 \mathrm{~mL}$ ice-cold sodium borate buffer $(\mathrm{pH}=8.8)$ containing $1.4 \mathrm{mM} 2$-mercaptoethanol and $0.1 \mathrm{~g}$ of polyvinyl pyrrolidone. Then the mixture was centrifuged at 10,000 rpm for $25 \mathrm{~min}$. To the aliquot $(0.1 \mathrm{~mL})$, add $0.1 \mathrm{M}$ tri-sodium borate buffer ( $\mathrm{pH} 8.5$ ) and $0.5 \mathrm{~mL}$ of $12 \mathrm{mM} \mathrm{L}$-phenylalanine. The final volume was then made $3 \mathrm{~mL}$ by adding deionized water and kept for incubation at $30^{\circ} \mathrm{C}$ for $30 \mathrm{~min}$. Then the increase in absorbance was recorded at $270 \mathrm{~nm}$ for $5 \mathrm{~min}$. TAL activity 
was determined by measuring the amount of p-coumaric acid formed at $333 \mathrm{~nm}$ from L-tyrosine [131].

\subsubsection{Total Phenol and Total Flavonoid Content}

Total phenol content was determined by the method given by Haard [131]. First, $0.1 \mathrm{~mL}$ of the prepared sample was taken and diluted with $0.4 \mathrm{~mL}$ of distilled water. Then freshly prepaid Folin-Ciocalteu Reagent $(1 \mathrm{~N})(0.5 \mathrm{~mL})$ was added. After $3-4 \mathrm{~min}, 2 \mathrm{~mL}$ of

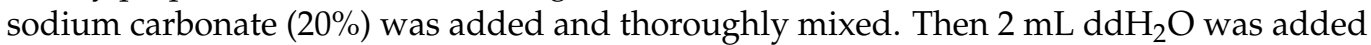
to each tube, making the final volume $5 \mathrm{~mL}$. The tubes were kept in boiling water for $1 \mathrm{~min}$. The absorbance was recorded at $650 \mathrm{~nm}$ using Shimadzu UV-1650 Spectrophotometer after cooling and kept in the dark for one hour. The color was read at $650 \mathrm{~nm}$, using the method of Malik (Malik and Singh 1980). The sample concentration was calculated as gallic acid equivalent (GE), and phenolic content was expressed in $\mathrm{mg} / \mathrm{g}$ of dry weight.

Total flavonoid content was determined by the colorimetric method developed by Woisky [132]. First, $0.1 \mathrm{~mL}$ of the already prepared sample was taken in test tubes and diluted by $0.4 \mathrm{~mL}$ of $\mathrm{dd}_{2} \mathrm{O}$, making the final volume $0.5 \mathrm{~mL}$. Then methanolic aluminum chloride $\left(\mathrm{AlCl}_{3}\right)$ was added, followed by $2 \mathrm{~mL}$ of potassium acetate (1M). Then $\mathrm{ddH}_{2} \mathrm{O}$ was added, making the final volume $5 \mathrm{~mL}$. The mixture was incubated at room temperature for $30 \mathrm{~min}$, and absorbance was recorded at $415 \mathrm{~nm}$. Total flavonoid content was estimated using rutin as the standard. Flavanoid content was expressed as $\mathrm{mg} / \mathrm{g}$ of dry extract.

\subsubsection{Determination of Total Reducing Power, DPPH and FRAP}

The total reducing power was assayed by the method given by Yen [133]. An aliquot of $100 \mu \mathrm{L}$ was mixed with $500 \mu \mathrm{L}$ of $1 \%$ potassium ferricyanide. Then the reaction mixture was incubated at $50{ }^{\circ} \mathrm{C}$ for $20 \mathrm{~min}$. Then $500 \mu \mathrm{l}$ of $10 \%$ TAA were added and then centrifuged at $2500 \mathrm{rpm}$ for $10 \mathrm{~min}$. Then $1.5 \mathrm{~mL}$ of distilled water were added to the supernatant. Finally, $1 \%$ of ferric chloride $(300 \mu \mathrm{L})$ was added, and absorbance was measured at $700 \mathrm{~nm}$.

The antioxidative scavenging activity was determined using a stable free radical 1 , 1 diphenyl 2-picryl hydrazine method. An aliquot (20-100 $\mu \mathrm{L})$ of the extract was mixed with $1 \mathrm{~mL}$ of ethanol and $1 \mathrm{~mL}$ DPPH. The reaction mixture was incubated in the dark for $10 \mathrm{~min}$, and the absorbance was read at $517 \mathrm{~nm}$. The percentage inhibition activity was calculated by using the formula [134]:

$$
\text { Percentage inhibition }=\mathbf{A}_{\text {Control }}-\mathbf{A}_{\text {Sample }} / \mathbf{A}_{\text {Control }} \times 100
$$

The FRAP assay was performed using Benzie's [135] method with some modifications. An aliquot $(10-50 \mu \mathrm{L})$ of extracts was mixed with $0.9 \mathrm{~mL}$ FRA reagent, and the mixture was kept in the dark for $10 \mathrm{~min}$. The solution was diluted with $\mathrm{ddH}_{2} \mathrm{O}$. Then, the absorbance of the blueish product, thus, formed was measured at $593 \mathrm{~nm}$. Then the results were expressed in $\mu \mathrm{M} \mathrm{Fe}(\mathrm{II}) / \mathrm{g}$ dry mass.

4.8.4. Determination of Hydrogen Peroxide (H2O2) and Superoxide Radical (SOD) Scavenging Activity

Hydrogen peroxide scavenging activity was assayed by using the method of Ebrahimzadeh [136]. An aliquot of 10-50 $\mu \mathrm{L}$ of the extract was added to $600 \mu \mathrm{L}$ of $40 \mathrm{mM}$ $\mathrm{H}_{2} \mathrm{O}_{2}$ in phosphate buffer. Then phosphate buffer ( $\mathrm{pH}$ 7.4) was added to make the final volume $5 \mathrm{~mL}$. The reaction mixture was incubated at room temperature for $10 \mathrm{~min}$, and absorbance was measured at $230 \mathrm{~nm}$ against the blank, where no $\mathrm{H}_{2} \mathrm{O}_{2}$ was added. The following formulae determined percentage inhibition:

$$
\text { Percentage inhibition }=\mathbf{A}_{\text {Control }}-\mathbf{A}_{\text {Sample }} / \mathbf{A}_{\text {Control }} \times 100
$$

SOD scavenging activity was determined using the method given by Beauchamp [137]. First, $20-100 \mu \mathrm{L}$ of extracts were mixed with nitro blue tetrazolium chloride (NBT) $(0.1 \mathrm{~mL})$. The reaction was initiated by $0.2 \mathrm{~mL}$ PMS (dissolved in $2.8 \mathrm{~mL}$ of $50 \mathrm{mM}$ phosphate 
buffer having $\mathrm{pH}$ 7.6). The mixture was kept under fluorescent light for $20 \mathrm{~min}$. After the formation of formazan color, the absorbance was measured at $562 \mathrm{~nm}$. The percentage inhibition of SOD anion generation was estimated using the formula:

$$
\text { Percentage scavenging }=\left(\mathbf{A}_{\text {control }}-\mathbf{A}_{\text {sample }}\right) / \mathbf{A}_{\text {control }} \times 100
$$

\subsection{Statistical Analysis}

The experiments were performed in triplicates $(n=3)$ except for growth parameters FW, BA and RWC (where $\mathrm{n}=10$ ). Data were treated with two-way ANOVA employing Graphpad Prism 6.0. The results were displayed as the arithmetic mean \pm standard error (SE) and the statistical differences at 0.05 probability level were identified by Tukey's post hoc test. The multivariate data analysis was performed by MetaboAnalyst software 5.0 (https: / / www.metaboanalyst.ca, accessed on 1 May 2021). To normalize the scale of abundance, the percent difference for every metabolite was log-transformed to base 2 preceding to data analysis using MetaboAnalyst software 5.0.

\section{Conclusions}

The present work illustrates the considerable distinction in cellular activity between the salt-treated and salt aided with zinc in mungbean. Under increased $\mathrm{NaCl}$ concentrations, salt-treated seedlings cultivar exhibit decreased root and shoot lengths, fresh weight, biomass accumulation and RWC in comparison to zinc treated salt-stressed plants. Salt treated plants also reveal high $\mathrm{H}_{2} \mathrm{O}_{2}$ content, which is associated with symptoms of oxidative damage, which go along with increased lipid peroxidation and electrolyte leakage. While the salt-stressed plants treated with $\mathrm{Zn}$ show less oxidative damage, comparatively. Likewise, the enzymatic antioxidant activity of $\mathrm{Zn}$ treated salt-stressed plants was much more than salt-stressed plants. Precisely, we can conclude that salinity and Zn combination elicited widespread physiological responses in mungbean plants, where $\mathrm{Zn}$ alleviates the harmful effects of salt and confer tolerance against the $\mathrm{NaCl}$ stress. The results obtained could be well thought-out as a nutrient administration tool for plants encountering stress conditions.

Supplementary Materials: The following are available online at https://www.mdpi.com/article/ 10.3390/plants10051005/s1, Figure S1: Effects of $\mathrm{NaCl}$ and Interactive effect of $\mathrm{NaCl}$ and $\mathrm{Zn}$ on mungbean. Figure S2: Effects of $\mathrm{NaCl}$ and Interactive effect of $\mathrm{NaCl}$ and $\mathrm{Zn}$ on Heatmap based on the activities of total chlorophyll (total $\mathrm{Chl}$ ), hydrogen peroxide (H2O2), lipid peroxidation (MDA), proline, protein, sugar, superoxide dismutase (SOD), catalase (CAT), ascorbate peroxidase (APX), peroxidase (POD), glutathione reductase (GR) and glutathione-s-transferase (GST) in mung bean. Heat map scale bars are shown $(+1.5)$ to $(-1.5)$ and the classes $0-5$ represent the treatments in the study: Blank (0); Zn (1); $150 \mathrm{mM} \mathrm{NaCl}$ (2); $150 \mathrm{mM} \mathrm{NaCl}+\mathrm{Zn}$ (3); $200 \mathrm{mM} \mathrm{NaCl}$ (4); $200 \mathrm{mM}$ $\mathrm{NaCl}+\mathrm{Zn}$ (5) The white color (1.5) indicates strong up-regulation of the metabolites, the red color $(-1.5)$ indicates strong down-regulation of metabolites and the yellow colors (1) indicate moderate up-regulation of metabolites.

Author Contributions: H.S.A.-Z., H.F.A., K.R.H. and R.U.R. designed the experimental work. K.R.H. and R.U.R. carried out the statistical analysis. H.F.A., K.R.H. and R.U.R. wrote and revised the manuscript. All authors have read and agreed to the published version of the manuscript.

Funding: This project was funded by the Deanship of Scientific Research (DSR) at King Abdulaziz University, Jeddah, under grant No. G: 283-130-1439. The authors, therefore, acknowledge with thanks DSR for technical and financial support.

Institutional Review Board Statement: Not applicable.

Informed Consent Statement: Not applicable.

Data Availability Statement: Not applicable. 
Acknowledgments: This project was funded by the Deanship of Scientific Research (DSR) at King Abdulaziz University, Jeddah, under grant No. G: 283-130-1439. The authors, therefore, acknowledge with thanks DSR for technical and financial support.

Conflicts of Interest: The authors declare that there is no conflict of interest among them.

\section{References}

1. Munns, R.; Tester, M. Mechanisms of salinity tolerance. Annu. Rev. Plant Biol. 2008, 59, 651-681. [CrossRef] [PubMed]

2. Munns, R.; Gilliham, M.J. Salinity tolerance of crops-What is the cost? New Phytol. 2015, 208, 668-673. [CrossRef]

3. FAO. FAO Cereal Supply and Demand Brief; FAO: Rome, Italy, 2015.

4. Hachicha, M. Salty soils and their development in Tunisia. Sci. Glob. Chang. Drought 2007, 18, 45-50.

5. Kalaji, H.; Nalborczyk, E. Gas exchange of barley seedlings growing under salinity stress. Photosynthetica 1991, 25, 197-202.

6. Parida, A.K.; Das, A.B. Salt tolerance and salinity effects on plants: A review. Ecotoxicol. Environ. Saf. 2005, 60, 324-349. [CrossRef]

7. Munns, R. Comparative physiology of salt and water stress. Plant Cell Environ. 2002, 25, 239-250. [CrossRef]

8. Foyer, C.H.; Lelandais, M.; Kunert, K.J. Photooxidative stress in plants. Physiol. Plant. 1994, 92, 696-717. [CrossRef]

9. Bascola, P.R.; Menossi, M.; Jorge, R.A. Aluminum-induced oxidative stress in plants. Photochemistry 2003, 62, 181-189. [CrossRef]

10. Gill, S.S.; Tuteja, N. Reactive oxygen species and antioxidant machinery in abiotic stress tolerance in crop plants. Plant Physiol. Biochem. 2010, 48, 909-930. [CrossRef]

11. Passardi, F.; Theiler, G.; Zamocky, M.; Cosio, C.; Rouhier, N.; Teixera, F.; Margis-Pinheiro, M.; Ioannidis, V.; Penel, C.; Falquet, L.; et al. PeroxiBase: The peroxidase database. Phytochemistry 2007, 68, 1605-1611. [CrossRef] [PubMed]

12. Sakamoto, A.; Murata, N. The role of glycine betaine in the protection of plants from stress: Clues from transgenic plants. Plant Cell Environ. 2002, 25, 163-171. [CrossRef]

13. Debona, D.; Rodrigues, F.A.; Datnoff, L.E. Silicon's role in abiotic and biotic plant stresses. Annu. Rev. Phytopathol. 2017, 55, 85-107. [CrossRef] [PubMed]

14. Murmu, K.M.S.; Bera, C.K.K.P.S. Exogenous Proline and Glycine Betaine in Plants under Stress Tolerance. Int. J. Curr. Microbiol. Appl. Sci. 2017, 6, 901-913. [CrossRef]

15. Broadley, M.; Brown, P.; Cakmak, I.; Rengel, Z.; Zhao, F.-J. Function of Nutrients: Micronutrients, in Marschner's Mineral Nutrition of Higher Plants; Elsevier: Amsterdam, The Netherlands, 2012; pp. 191-248.

16. Zafar, S.; Ashraf, M.Y.; Saleem, M. Shift in Physiological and Biochemical Processes in Wheat Supplied with Zinc and Potassium under Saline Condition. J. Plant Nutr. 2017, 41, 19-28. [CrossRef]

17. Parker, D.R.; Aguilera, J.J.; Thomason, D.N. Zinc-phosphorus interactions in two cultivars of tomato (Lycopersicon esculentum L.) grown in chelator-buffered nutrient solutions. Plant Soil 1992, 143, 163-177. [CrossRef]

18. Sharma, P.N.; Bisht, S.S.; Kumar, N. Effect of zinc deficiency on chlorophyll content, photosynthesis and water relations of cauliflower plants. Photosynthetica 1994, 30, 353-359.

19. Bettger, W.J.; O'Dell, B.L. A critical physiological role of zinc in the structure and function of biomembranes. Life Sci. 1981, 28, 1425-1438. [CrossRef]

20. Vallee, B.L.; Auld, D.S. Zinc coordination, function, and structure of zinc enzymes and other proteins. Biochemistry 1990, 29, 5647-5659. [CrossRef]

21. Aravind, P.; Prasad, M. Zinc protects chloroplasts and associated photochemical functions in cadmium exposed Ceratophyllum demersum L., a freshwater macrophyte. Plant Sci. 2004, 166, 1321-1327. [CrossRef]

22. Cakmak, I.; Marschner, H. Zinc-dependent changes in ESR signals, NADPH oxidase and plasma membrane permeability in cotton roots. Physiol. Plant. 1988, 73, 182-186. [CrossRef]

23. Marschner, H.; Cakmak, I. High Light Intensity Enhances Chlorosis and Necrosis in Leaves of Zinc, Potassium, and Magnesium Deficient Bean (Phaseolus vulgaris) Plants. J. Plant Physiol. 1989, 134, 308-315. [CrossRef]

24. Broadley, M.R.; White, P.J.; Hammond, J.P.; Zelko, I.; Lux, A. Zinc in plants. New Phytol. 2007, 173, 677-702. [CrossRef]

25. Graham, R.D.; Welch, R.M. Breeding for Staple Food Crops with High Micronutrient Density; International Food Policy Research Institute: Washington, DC, USA, 1996; Volume 3.

26. Alharby, H.F.; Al-Zahrani, H.S.; Hakeem, K.R.; Iqbal, M. Identification of physiological and biochemical markers for salt (NaCl) stress in the seedlings of mungbean [Vigna radiata (L.) Wilczek] genotypes. Saudi J. Biol. Sci. 2019, 26, 1053-1060. [CrossRef] [PubMed]

27. Shah, W.H.; Rasool, A.; Saleem, S.; Mushtaq, N.U.; Tahir, I.; Hakeem, K.R.; Rehman, R.U. Understanding the Integrated Pathways and Mechanisms of Transporters, Protein Kinases, and Transcription Factors in Plants under Salt Stress. Int. J. Genom. 2021, 2021, 1-16. [CrossRef] [PubMed]

28. Kalaji, H.M.; Račková, L.; Paganová, V.; Swoczyna, T.; Rusinowski, S.; Sitko, K. Can chlorophyll-a fluorescence parameters be used as bio-indicators to distinguish between drought and salinity stress in Tilia cordata Mill? Environ. Exp. Bot. 2018, 152, 149-157. [CrossRef]

29. Weisany, W.; Sohrabi, Y.; Heidari, G.; Siosemardeh, A. Changes in antioxidant enzymes activity and plant performance by salinity stress and zinc application in soybean (Glycine max L.). Plant Omics 2012, 5, 60.

30. Hussein, M.M.; Abou-Baker, N.H. Growth and mineral status of moringa plants as affected by silicate and salicylic acid under salt stress. Int. J. Plant Soil Sci. 2014, 3, 163-177. [CrossRef] 
31. Amira, S.S.; Souad, A.E.F.; Essam, D.; Soliman, A.S.; El-Feky, S.A.; Darwish, E. Alleviation of salt stress on Moringa peregrina using foliar application of nanofertilizers. J. Hortic. For. 2015, 7, 36-47. [CrossRef]

32. Hussein, M.M.; Abou-Baker, N.H. The contribution of nano-zinc to alleviate salinity stress on cotton plants. R. Soc. Open Sci. 2018, 5, 171809. [CrossRef]

33. Hafeez, B.; Khanif, Y.M.; Saleem, M. Role of Zinc in Plant Nutrition- A Review. Am. J. Exp. Agric. 2013, 3, 374-391. [CrossRef]

34. Galal, A. Physico-chemical changes in karkade (Hibiscus sabdariffa L.) seedlings responding to salt stress. Acta Biol. Hung. 2017, 68, 73-87. [CrossRef] [PubMed]

35. Weisany, W.; Sohrabi, Y.; Heidari, G.; Siosemardeh, A. Physiological responses of soybean (Glycine max L.) to zinc application under salinity stress. Aust. J. Crop Sci. 2011, 5, 1441-1447.

36. Hayat, S.; Hayat, Q.; Alyemeni, M.N.; Wani, A.S.; Pichtel, J.; Ahmad, A. Role of proline under changing environments: A review. Plant Signal. Behav. 2012, 7, 1456-1466. [CrossRef]

37. Iqbal, N.; Umar, S.; Khan, N.A. Nitrogen availability regulates proline and ethylene production and alleviates salinity stress in mustard (Brassica juncea). J. Plant Physiol. 2015, 178, 84-91. [CrossRef]

38. Ahmad, P.; Ahanger, M.A.; Alyemeni, M.N.; Wijaya, L.; Egamberdieva, D.; Bhardwaj, R.; Ashraf, M. Zinc application mitigates the adverse effects of $\mathrm{NaCl}$ stress on mustard [Brassica juncea (L.) Czern \& Coss] through modulating compatible organic solutes, antioxidant enzymes, and flavonoid content. J. Plant Interactions 2017, 12, 429-437. [CrossRef]

39. El-Tayeb, M.A. Response of barley grains to the interactive e.ect of salinity and salicylic acid. Plant Growth Regul. 2005, 45, 215-224. [CrossRef]

40. Fang, Z.; Solomos, T.; Bouwkamp, J.C. Chlorophyllase activities and chlorophyll degradation during leaf senescence in nonyellowing mutant and wild type of Phaseolus vulgaris L. J. Exp. Bot. 1998, 49, 503-510. [CrossRef]

41. Weisany, W.; Sohrabi, Y.; Heidari, G.; Siosemardeh, A.; Badakhshan, H. Effects of Zinc Application on Growth, Absorption and Distribution of Mineral Nutrients Under Salinity Stress in Soybean (Glycine Max L.). J. Plant Nutr. 2014, 37, 2255-2269. [CrossRef]

42. Samreen, T.; Humaira; Shah, H.U.; Ullah, S.; Javid, M. Zinc effect on growth rate, chlorophyll, protein and mineral contents of hydroponically grown mungbeans plant (Vigna radiata). Arab. J. Chem. 2017, 10, S1802-S1807. [CrossRef]

43. Logani, M.K.; Davies, R.E. Lipid oxidation: Biologic effects and antioxidants-A review. Lipids 1980, 15, 485-495. [CrossRef]

44. Tavallali, V.; Rahemi, M.; Eshghi, S.; Kholdebarin, B. Zinc alleviates salt stress and increases antioxidant enzyme activity in the leaves of pistachio (Pistacia vera L.'Badami') seedlings. Turk. J. Agric. For. 2010, 34, 349-359.

45. Rasool, S.; Ahmad, A.; Siddiqi, T.O.; Ahmad, P. Changes in growth, lipid peroxidation and some key antioxidant enzymes in chickpea genotypes under salt stress. Acta Physiol. Plant. 2012, 35, 1039-1050. [CrossRef]

46. Hussein, M.; Embiale, A.; Husen, A.; Arem, I.M.; Iqbal, M. Salinity-induced modulation of plant growth and photosynthetic parameters in faba bean (Vicia faba) cultivars. Pak. J. Bot. 2017, 49, 867-877.

47. Shahriaripour, R.; Pour, A.T.; Mozaffari, V.; Dashti, H.; Adhami, E. Effects of salinity and soil zinc application on growth and chemical composition of pistachio seedlings. J. Plant Nutr. 2010, 33, 1166-1179. [CrossRef]

48. Tavallali, V.; Rahemi, M.; Maftoun, M.; Panahi, B.; Karimi, S.; Ramezanian, A.; Vaezpour, M. Zinc influence and salt stress on photosynthesis, water relations, and carbonic anhydrase activity in pistachio. Sci. Hortic. 2009, 123, 272-279. [CrossRef]

49. Galal, A. Exogenous application of zinc mitigates the deleterious effects in eggplant grown under salinity stress. J. Plant Nutr. 2019, 42, 915-927. [CrossRef]

50. Lutts, S.; Kinet, J.M.; Bouharmont, J. NaCl-induced senescence in leaves of rice (Oryza sativa L.) cultivars differing in salinity resistance. Ann. Bot. 1996, 78, 389-398. [CrossRef]

51. Chen, T.H.; Murata, N. Enhancement of tolerance of abiotic stress by metabolic engineering of betaines and other compatible solutes. Curr. Opin. Plant Biol. 2002, 5, 250-257. [CrossRef]

52. Abebe, T.; Guenzi, A.C.; Martin, B.; Cushman, J.C. Tolerance of Mannitol-Accumulating Transgenic Wheat to Water Stress and Salinity. Plant Physiol. 2003, 131, 1748-1755. [CrossRef]

53. Shah, W.H.; Rasool, A.; Tahir, I.; Rehman, R.U. Exogenously applied selenium (Se) mitigates the impact of salt stress in Setaria italica L. and Panicum miliaceum L. Nucleus 2020, 63, 327-339. [CrossRef]

54. Lawlor, D.W.; Cornic, G. Photosynthetic carbon assimilation and associated metabolism in relation to water deficits in higher plants. Plant Cell Environ. 2002, 25, 275-294. [CrossRef]

55. Wang, Z.-Q.; Yuan, Y.-Z.; Ou, J.-Q.; Lin, Q.-H.; Zhang, C.-F. Glutamine synthetase and glutamate dehydrogenase contribute differentially to proline accumulation in leaves of wheat (Triticum aestivum) seedlings exposed to different salinity. J. Plant Physiol. 2007, 164, 695-701. [CrossRef]

56. Ahanger, M.A.; Tyagi, S.R.; Wani, M.R.; Ahmad, P. Drought tolerance: Role of organic osmolytes, growth regulators, and mineral nutrients. In Physiological Mechanisms and Adaptation Strategies in Plants under Changing Environment; Springer: Berlin, Germany, 2014; pp. 25-55.

57. Ahanger, M.A.; Agarwal, R.M.; Tomar, N.S.; Shrivastava, M. Potassium induces positive changes in nitrogen metabolism and antioxidant system of oat (Avena sativa L. cultivar Kent). J. Plant Interact. 2015, 10, 211-223. [CrossRef]

58. Ahmad, P.; Sarwat, M.; Bhat, N.A.; Wani, M.R.; Kazi, A.G.; Tran, L.-S.P. Alleviation of Cadmium Toxicity in Brassica juncea L. (Czern. \& Coss.) by Calcium Application Involves Various Physiological and Biochemical Strategies. PLoS ONE 2015, 10, e0114571. [CrossRef] 
59. Ahmad, P.; Latef, A.A.A.; Hashem, A.; Abd_Allah, E.F.; Gucel, S.; Tran, L.-S.P. Nitric oxide mitigates salt stress by regulating levels of osmolytes and antioxidant enzymes in chickpea. Front. Plant Sci. 2016, 7, 347. [CrossRef] [PubMed]

60. Rajendrakumar, C.S.; Suryanarayana, T.; Reddy, A.R. DNA helix destabilization by proline and betaine: Possible role in the salinity tolerance process. FEBS Lett. 1997, 410, 201-205. [CrossRef]

61. Ashraf, M.A.; Akbar, A.; Parveen, A.; Rasheed, R.; Hussain, I.; Iqbal, M. Phenological application of selenium differentially improves growth, oxidative defense and ion homeostasis in maize under salinity stress. Plant Physiol. Biochem. 2018, 123, 268-280. [CrossRef]

62. Aziz, A.; Akram, N.A.; Ashraf, M. Influence of natural and synthetic vitamin C (ascorbic acid) on primary and secondary me-tabolites and associated metabolism in quinoa (Chenopodium quinoa Willd.) plants under water deficit regimes. Plant Physiol. Biochem. 2018, 123, 192-203. [CrossRef]

63. Feki, K.; Tounsi, S.; Brini, F. Comparison of an antioxidant system in tolerant and susceptible wheat seedlings in response to salt stress. Span. J. Agric. Res. 2018, 15, e0805. [CrossRef]

64. Iqbal, M.N.; Rasheed, R.; Ashraf, M.A.; Hussain, I. Exogenously applied zinc and copper mitigate salinity effect in maize (Zea mays L.) by improving key physiological and biochemical attributes. Environ. Sci. Pollut. Res. 2018, 25, 23883-23896. [CrossRef]

65. Amiri, A.; Baninasab, B.; Ghobadi, C.; Khoshgoftarmanesh, A.H. Zinc soil application enhances photosynthetic capacity and antioxidant enzyme activities in almond seedlings affected by salinity stress. Photosynthetica 2016, 54, 267-274. [CrossRef]

66. Torabian, S.; Zahedi, M.; Khoshgoftar, A.H. Effects of foliar spray of nano-particles of $\mathrm{FeSO}_{4}$ on the growth and ion content of sunflower under saline condition. J. Plant Nutr. 2017, 40, 615-623. [CrossRef]

67. Mallik, S.; Nayak, M.; Sahu, B.B.; Panigrahi, A.K.; Shaw, B.P. Response of antioxidant enzymes to high NaCl concentration in different salt-tolerant plants. Biol. Plant. 2011, 55, 191-195. [CrossRef]

68. Mittova, V.; Guy, M.; Tal, M.; Volokita, M. Salinity up-regulates the antioxidative system in root mitochondria and peroxisomes of the wild salt-tolerant tomato species Lycopersicon pennellii. J. Exp. Bot. 2004, 55, 1105-1113. [CrossRef]

69. Wani, A.S.; Ahmad, A.; Hayat, S.; Fariduddin, Q. Salt-induced modulation in growth, photosynthesis and antioxidant system in two varieties of Brassica juncea. Saudi J. Biol. Sci. 2013, 20, 183-193. [CrossRef] [PubMed]

70. Najami, N.; Janda, T.; Barriah, W.; Kayam, G.; Tal, M.; Guy, M.; Volokita, M. Ascorbate peroxidase gene family in tomato: Its identification and characterization. Mol. Genet. Genom. 2007, 279, 171-182. [CrossRef]

71. Abbaspour, H. Effect of salt stress on lipid peroxidation, antioxidative enzymes, and proline accumulation in pistachio plants. J. Med. Plants Res. 2012, 6, 526-529. [CrossRef]

72. Cakmak, I. Tansley Review No. 111: Possible roles of zinc in protecting plant cells from damage by reactive oxygen species. New Phytol. 2000, 146, 185-205. [CrossRef] [PubMed]

73. Ahmad, P.; Jaleel, C.A.; Salem, M.A.; Nabi, G.; Sharma, S. Roles of enzymatic and nonenzymatic antioxidants in plants during abiotic stress. Crit. Rev. Biotechnol. 2010, 30, 161-175. [CrossRef]

74. Dixon, D.P.; Skipsey, M.; Edwards, R. Roles for glutathione transferases in plant secondary metabolism. Phytochemistry 2010, 71, 338-350. [CrossRef] [PubMed]

75. Gapińska, M.; Skłodowska, M.; Gabara, B. Effect of short- and long-term salinity on the activities of antioxidative enzymes and lipid peroxidation in tomato roots. Acta Physiol. Plant. 2007, 30, 11-18. [CrossRef]

76. Margis, R.; Dunand, C.; Teixeira, F.K.; Margis-Pinheiro, M. Glutathione peroxidase family-an evolutionary overview. FEBS J. 2008, 275, 3959-3970. [CrossRef] [PubMed]

77. Zhai, C.-Z.; Zhao, L.; Yin, L.J.; Chen, M.; Wang, Q.Y.; Li, L.C.; Xu, Z.S.; Ma, Y.Z. Two wheat glutathione peroxidase genes whose products are located in chloroplasts improve salt and $\mathrm{H}_{2} \mathrm{O}_{2}$ tolerances in Arabidopsis. PLoS ONE 2013, 8, e73989. [CrossRef]

78. Passaia, G.; Fonini, L.S.; Caverzan, A.; Jardim-Messeder, D.; Christoff, A.P.; Gaeta, M.L.; Mariath, J.E.D.A.; Margis, R.; MargisPinheiro, M. The mitochondrial glutathione peroxidase GPX3 is essential for $\mathrm{H}_{2} \mathrm{O}_{2}$ homeostasis and root and shoot development in rice. Plant Sci. 2013, 208, 93-101. [CrossRef]

79. Passaia, G.; Caverzan, A.; Fonini, L.S.; Carvalho, F.E.L.; Silveira, J.A.G.; Margis-Pinheiro, M. Chloroplastic and mitochondrial GPX genes play a critical role in rice development. Biol. Plant. 2014, 58, 375-378. [CrossRef]

80. Yamane, K.; Mitsuya, S.; Kawasaki, M.; Taniguchi, M.; Miyake, H. Antioxidant Capacity and Damages Caused by Salinity Stress in Apical and Basal Regions of Rice Leaf. Plant Prod. Sci. 2009, 12, 319-326. [CrossRef]

81. Rao, A.S.V.C.; Reddy, A.R. Glutathione Reductase: A Putative Redox Regulatory System in Plant Cells. In Sulfur Assimilation and Abiotic Stress in Plants; Springer: Berlin, Germany, 2008; pp. 111-147.

82. Rao, K.; Raghavendra, A.; Reddy, K. Physiology and Molecular Biology of Stress Tolerance; Springer: Berlin, Germany, 2006.

83. Gill, S.S.; Anjum, N.A.; Hasanuzzaman, M.; Gill, R.; Trivedi, D.K.; Ahmad, I.; Pereira, E.; Tuteja, N. Glutathione and glutathione reductase: A boon in disguise for plant abiotic stress defense operations. Plant Physiol. Biochem. 2013, 70, 204-212. [CrossRef]

84. Saeidnejad, A.H.; Kafi, M.; Pessarakli, M. Interactive Effects of Salinity Stress and Zn Availability on Physiological Properties, Antioxidants Activity and Micronutrients' Content of Wheat (Triticum aestivum) plants. Commun. Soil Sci. Plant Anal. 2016, 47, 1048-1057. [CrossRef]

85. Taïbi, K.; Taïbi, F.; Abderrahim, L.A.; Ennajah, A.; Belkhodja, M.; Mulet, J.M. Effect of salt stress on growth, chlorophyll content, lipid peroxidation and antioxidant defence systems in Phaseolus vulgaris L. South Afr. J. Bot. 2016, 105, 306-312. [CrossRef]

86. Martinez, V.; Mestre, T.C.; Rubio, F.; Girones-Vilaplana, A.; Moreno, D.A.; Mittler, R.; Rivero, R.M. Accumulation of Flavonols over Hydroxycinnamic Acids Favors Oxidative Damage Protection under Abiotic Stress. Front. Plant Sci. 2016, 7, 838. [CrossRef] 
87. Neto, A.D.D.A.; Prisco, J.T.; Enéas-Filho, J.; De Abreu, C.E.B.; Gomes-Filho, E. Effect of salt stress on antioxidative enzymes and lipid peroxidation in leaves and roots of salt-tolerant and salt-sensitive maize genotypes. Environ. Exp. Bot. 2006, 56, 87-94. [CrossRef]

88. Sharma, A.; Shahzad, B.; Rehman, A.; Bhardwaj, R.; Landi, M.; Zheng, B. Response of Phenylpropanoid Pathway and the Role of Polyphenols in Plants under Abiotic Stress. Molecules 2019, 24, 2452. [CrossRef]

89. Chen, S.; Wu, F.; Li, Y.; Qian, Y.; Pan, X.; Li, F.; Wang, Y.; Wu, Z.; Fu, C.; Lin, H.; et al. NtMYB4 and NtCHS1 are critical factors in the regulation of flavonoid biosynthesis and are involved in salinity responsiveness. Front. Plant Sci. 2019, 10, 178. [CrossRef]

90. Bistgani, Z.E.; Hashemi, M.; DaCosta, M.; Craker, L.; Maggi, F.; Morshedloo, M.R. Effect of salinity stress on the physiological characteristics, phenolic compounds and antioxidant activity of Thymus vulgaris L. and Thymus daenensis Celak. Ind. Crop. Prod. 2019, 135, 311-320. [CrossRef]

91. Al-Ghamdi, A.A.; Elansary, H.O. Synergetic effects of 5-aminolevulinic acid and Ascophyllum nodosum seaweed extracts on Asparagus phenolics and stress related genes under saline irrigation. Plant Physiol. Biochem. 2018, 129, 273-284. [CrossRef] [PubMed]

92. Macdonald, M.J.; D'Cunha, G.B. A modern view of phenylalanine ammonia lyase. Biochem. Cell Biol. 2007, 85, 273-282. [CrossRef] [PubMed]

93. Kováčik, J.; Bačkor, M. Phenylalanine Ammonia-Lyase and Phenolic Compounds in Chamomile Tolerance to Cadmium and Copper Excess. Water Air Soil Pollut. 2007, 185, 185-193. [CrossRef]

94. Luo, Z.-B.; He, X.-J.; Chen, L.; Tang, L. Effects of zinc on growth and antioxidant responses in Jatropha curcas seedlings. Int. J. Agric. Biol. 2010, 12, 119-124.

95. Maldonado, R.; Goñi, O.; Escribano, M.; Merodio, C. Regulation of phenylalanine ammonia-lyase enzyme in annona fruit: Kinetic characteristics and inhibitory effect of ammonia. J. Food Biochem. 2007, 31, 161-178. [CrossRef]

96. Gholizadeh, A. Effects of drought on the activity of phenylalanine ammonia lyase in the leaves and roots of maize inbreds. Aust. J. Basic Appl. Sci. 2011, 5, 952-956.

97. Koç, E.; İşlek, C.; Büyükkartal, H.N. Comparasion of phenylalanine ammonia lyase response to lead and zinc stress in different wheat genotypes. Commun. Fac. Sci. Univ. Ank. Ser. C 2018, 27, 37-44.

98. Wadhwa, N.; Joshi, U.N.; Mehta, N. Zinc Induced Enzymatic Defense Mechanisms in Rhizoctonia Root Rot Infected Clusterbean Seedlings. J. Bot. 2014, 2014, 1-7. [CrossRef]

99. Sarker, U.; Oba, S. Augmentation of leaf color parameters, pigments, vitamins, phenolic acids, flavonoids and antioxidant activity in selected Amaranthus tricolor under s alinity stress. Sci. Rep. 2018, 8, 1-9. [CrossRef] [PubMed]

100. Awika, J.M.; Rooney, L.W. Sorghum phytochemicals and their potential impact on human health. Phytochemistry 2004, 65, 1199-1221. [CrossRef] [PubMed]

101. Pokorny, J.; Yanishlieva, N.; Gordon, M.H. Antioxidants in Food: Practical Applications; CRC Press: Boca Raton, FL, USA, 2001.

102. Valifard, M.; Mohsenzadeh, S.; Kholdebarin, B.; Rowshan, V. Effects of salt stress on volatile compounds, total phenolic content and antioxidant activities of Salvia mirzayanii. S. Afr. J. Bot. 2014, 93, 92-97. [CrossRef]

103. Falcinelli, B.; Sileoni, V.; Marconi, O.; Perretti, G.; Quinet, M.; Lutts, S.; Benincasa, P. Germination under Moderate Salinity Increases Phenolic Content and Antioxidant Activity in Rapeseed (Brassica napus var oleifera Del.) Sprouts. Molecules 2017, 22, 1377. [CrossRef] [PubMed]

104. Ibrahim, M.H.; Jaafar, H.Z.E.; Karimi, E.; Ghasemzadeh, A. Primary, Secondary Metabolites, Photosynthetic Capacity and Antioxidant Activity of the Malaysian Herb Kacip Fatimah (Labisia Pumila Benth) Exposed to Potassium Fertilization under Greenhouse Conditions. Int. J. Mol. Sci. 2012, 13, 15321-15342. [CrossRef]

105. Ghasemzadeh, A.; Jaafar, H.Z.E.; Rahmat, A.; Wahab, P.E.M.; Halim, M.R.A. Effect of Different Light Intensities on Total Phenolics and Flavonoids Synthesis and Anti-oxidant Activities in Young Ginger Varieties (Zingiber officinale Roscoe). Int. J. Mol. Sci. 2010, 11, 3885-3897. [CrossRef]

106. Zhou, Y.; Tang, N.; Huang, L.; Zhao, Y.; Tang, X.; Wang, K. Effects of Salt Stress on Plant Growth, Antioxidant Capacity, Glandular Trichome Density, and Volatile Exudates of Schizonepeta tenuifolia Briq. Int. J. Mol. Sci. 2018, 19, 252. [CrossRef]

107. Taylor, L.P.; Grotewold, E. Flavonoids as developmental regulators. Curr. Opin. Plant Biol. 2005, 8, 317-323. [CrossRef]

108. Agati, G.; Biricolti, S.; Guidi, L.; Ferrini, F.; Fini, A.; Tattini, M. The biosynthesis of flavonoids is enhanced similarly by UV radiation and root zone salinity in L. vulgare leaves. J. Plant Physiol. 2011, 168, 204-212. [CrossRef]

109. Agati, G.; Azzarello, E.; Pollastri, S.; Tattini, M. Flavonoids as antioxidants in plants: Location and functional significance. Plant Sci. 2012, 196, 67-76. [CrossRef]

110. Winkel-Shirley, B. Biosynthesis of flavonoids and effects of stress. Curr. Opin. Plant Biol. 2002, 5, 218-223. [CrossRef]

111. Golkar, P.; Taghizadeh, M. In vitro evaluation of phenolic and osmolite compounds, ionic content, and antioxidant activity in safflower (Carthamus tinctorius L.) under salinity stress. Plant Cell Tissue Organ Cult. (PCTOC) 2018, 134, 357-368. [CrossRef]

112. Gharibi, S.; Tabatabaei, B.E.S.; Saeidi, G.; Goli, S.A.H. Effect of Drought Stress on Total Phenolic, Lipid Peroxidation, and Antioxidant Activity of Achillea Species. Appl. Biochem. Biotechnol. 2016, 178, 796-809. [CrossRef]

113. Sharma, V.; Ramawat, K.G. Salt stress enhanced antioxidant response in callus of three halophytes (Salsola baryosma, Trianthema triquetra, Zygophyllum simplex) of Thar Desert. Biologia 2014, 69, 178-185. [CrossRef] 
114. Khorasani Esmaeili, A.; Mat Taha, R.; Mohajer, S.; Banisalam, B. Antioxidant activity and total phenolic and flavonoid content of various solvent extracts from in vivo and in vitro grown Trifolium pratense L. (Red Clover). BioMed Res. Int. 2015, $2015,643285$. [CrossRef] [PubMed]

115. Mazaheri-Tirani, M.; Dayani, S. In vitro effect of zinc oxide nanoparticles on Nicotiana tabacum callus compared to ZnO micro particles and zinc sulfate $\left(\mathrm{ZnSO}_{4}\right)$. Plant Cell Tissue Organ Cult. (PCTOC) 2019, 140, 279-289. [CrossRef]

116. Keutgen, A.J.; Pawelzik, E. Quality and nutritional value of strawberry fruit under long term salt stress. Food Chem. 2008, 107, 1413-1420. [CrossRef]

117. Rice-Evans, C.; Miller, N.; Paganga, G. Antioxidant properties of phenolic compounds. Trends Plant Sci. 1997, 2, 152-159. [CrossRef]

118. Hoagland, D.R.; Arnon, D.I. The Water-culture Method for Growing Plants without Soil. Californian Agricultural Experimental Station. Circular No. 347; University of California: Berkeley, CA, USA, 1950.

119. Lichtenthaler, H.K. Chlorophylls and Carotenoids: Pigments of Photosynthetic Biomembranes. In Methods in Enzymology; Academic Press: Orlando, FL, USA, 1987; Volume 148, pp. 350-382.

120. Tabot, P.; Adams, J. Early responses of Bassia diffusa (Thunb.) Kuntze to submergence for different salinity treatments. South Afr. J. Bot. 2013, 84, 19-29. [CrossRef]

121. Cakmak, I.; Horst, W.J. Effect of aluminium on lipid peroxidation, superoxide dismutase, catalase, and peroxidase activities in root tips of soybean (Glycine max). Physiol. Plant. 1991, 83, 463-468. [CrossRef]

122. Velikova, V.; Yordanov, I.; Edreva, A. Oxidative stress and some antioxidant systems in acid rain-treated bean plants: Protective role of exogenous polyamines. Plant Sci. 2000, 151, 59-66. [CrossRef]

123. Dey, P.M. Oligosaccharides. In Methods in Plant Biochemistry; Elsevier: Amsterdam, The Netherlands, 1990; pp. 189-218.

124. Bates, L.S.; Waldren, R.P.; Teare, I.D. Rapid determination of free proline for water-stress studies. Plant Soil 1973, 39, $205-207$. [CrossRef]

125. Bradford, M.M. A rapid and sensitive method for the quantitation of microgram quantities of protein utilizing the principle of protein-dye binding. Anal. Biochem. 1976, 72, 248-254. [CrossRef]

126. Beyer, W.F., Jr.; Fridovich, I. Assaying for superoxide dismutase activity: Some large consequences of minor changes in conditions. Anal. Biochem. 1987, 161, 559-566. [CrossRef]

127. Aebi, H. Catalase in vitro. Methods Enzymol. 1984, 105, 121-126. [CrossRef]

128. Nakano, Y.; Asada, K. Hydrogen Peroxide is Scavenged by Ascorbate-specific Peroxidase in Spinach Chloroplasts. Plant Cell Physiol. 1981, 22, 867-880. [CrossRef]

129. Habig, W.H.; Jakoby, W.B. Assays for differentiation of glutathione S-Transferases. In Methods in Enzymology; Elsevier: Amsterdam, The Netherlands, 1981; pp. 398-405.

130. Foyer, C.H.; Halliwell, B. The presence of glutathione and glutathione reductase in chloroplasts: A proposed role in ascorbic acid metabolism. Planta 1976, 133, 21-25. [CrossRef]

131. Haard, N.F.; Wasserman, B. Induction of phenylalanine ammonia lyase in sweet potato (Ipomoea batatas) root by light irradiation and black rot infection. Physiol. Plant Pathol. 1976, 8, 207-213. [CrossRef]

132. Woisky, R.G.; Salatino, A. Analysis of propolis: Some parameters and procedures for chemical quality control. J. Apic. Res. 1998, 37, 99-105. [CrossRef]

133. Yen, G.-C.; Chen, H.-Y. Antioxidant Activity of Various Tea Extracts in Relation to Their Antimutagenicity. J. Agric. Food Chem. 1995, 43, 27-32. [CrossRef]

134. Moon, J.-H.; Terao, J. Antioxidant Activity of Caffeic Acid and Dihydrocaffeic Acid in Lard and Human Low-Density Lipoproteint. J. Agric. Food Chem. 1998, 46, 5062-5065. [CrossRef]

135. Benzie, I.F.F.; Strain, J.J. The ferric reducing ability of plasma (FRAP) as a measure of "antioxidant power": The FRAP assay. Anal. Biochem. 1996, 239, 70-76. [CrossRef] [PubMed]

136. Ebrahimzadeh, M.A.; Nabavi, S.M.; Nabavi, S.F.; Bahramian, F.; Bekhradnia, A.R. Antioxidant and free radical scavenging activity of H. officinalis L. var. angustifolius, V. odorata, B. hyrcana and C. speciosum. Pak. J. Pharm. Sci. 2010, 23, $29-34$.

137. Beauchamp, C.; Fridovich, I. Superoxide dismutase: Improved assays and an assay applicable to acrylamide gels. Anal. Biochem. 1971, 44, 276-287. [CrossRef] 